NBER WORKING PAPER SERIES

\title{
EQUITY VOLATILITY AND CORPORATE BOND YIELDS
}

\author{
John Y. Campbell \\ Glen B. Taksler \\ Working Paper 8961 \\ http://www.nber.org/papers/w8961 \\ NATIONAL BUREAU OF ECONOMIC RESEARCH \\ 1050 Massachusetts Avenue \\ Cambridge, MA 02138 \\ May 2002
}

We are grateful to Peter Hecht, Jeremy Stein, and an anonymous referee for helpful comments, and to Vardges Levonyan for able research assistance. The views expressed herein are those of the authors and not necessarily those of the National Bureau of Economic Research.

(C) 2002 by John Y. Campbell and Glen B. Taksler. All rights reserved. Short sections of text, not to exceed two paragraphs, may be quoted without explicit permission provided that full credit, including $\mathbb{C}$ notice, is given to the source. 
Equity Volatility and Corporate Bond Yields

John Y. Campbell and Glen B. Taksler

NBER Working Paper No. 8961

May 2002

JEL No. G12

\begin{abstract}
This paper explores the effect of equity volatility on corporate bond yields. Panel data for the late 1990 's show that idiosyncratic firm-level volatility can explain as much cross-sectional variation in yields as can credit ratings. This finding, together with the upward trend in idiosyncratic equity volatility documented by Campbell, Lettau, Malkiel, and Xu (2001), helps to explain recent increases in corporate bond yields.
\end{abstract}

John Y. Campbell

Department of Economics

Harvard University

Littauer Center 213

Cambridge, MA 02138

and NBER

john_campbell@harvard.edu

http://post.economics.harvard.edu/faculty/campbell/campbell.html

Glen B. Taksler

Department of Economics

Harvard University

Littauer Center

Cambridge, MA 02138

taksler@fas.harvard.edu 
During the late 1990's, the US equity and corporate bond markets behaved very differently. As displayed in Figure 1, stock prices rose strongly, while at the same time corporate bonds performed poorly. The proximate cause of the low returns on corporate bonds was a tendency for the yields on both seasoned and newly issued corporate bonds to increase relative to the yields of US Treasury securities. These increases in corporate-Treasury yield spreads are striking because they occurred at a time when stock prices were rising; the optimism of stock market investors did not seem to be shared by investors in the corporate bond market.

There are several reasons why the prices of corporate bonds might diverge from the prices of corporate equities. First, stock prices will increase if investors become more optimistic about future corporate profits. Optimistic expectations benefit stock prices much more than bond prices, since stockholders receive all residual profits while corporate bondholders receive no more than the promised payments of principal and interest. This explanation does not account for the behavior of corporate bond yields in the late 1990's, however, because yield spreads on corporate bonds over Treasuries should fall, not rise, if investors become optimistic about corporate profits and thus reduce their expected probabilities of default. Second, there might be a composition effect if corporate bonds are issued by different companies than those that dominate value-weighted equity indexes. Third, an increase in the liquidity premium on corporate bonds relative to Treasury bonds might drive down corporate bond prices without any effect on equity prices. Fourth, the yields on newly issued corporate bonds might vary because of changes in the special features of these bonds, for example, an increase in the value of call provisions. Such an increase would drive down the prices and drive up the yields on newly issued bonds, but it would not have any effect on seasoned bond prices. Finally, volatility has opposite effects on stock and bond prices. Given expected profits, volatility of firm value hurts bondholders because it increases the probability of default; it has a corresponding positive effect for equityholders. Thus volatility should drive up the yields on both new and seasoned corporate bonds.

Merton (1974) initiated the modern analysis of corporate debt by pointing out that the holders of risky corporate bonds can be thought of as owners of riskless bonds who have issued put options to the holders of the firm's equity. When volatility increases, the value of the put options increases, benefiting equityholders at the expense of bondholders. The volatility that is relevant for option value, and thus for corporate debt, is total firm volatility, including both idiosyncratic volatility and systematic or market-wide volatility. This is important because idiosyncratic volatility can move 
very differently from market-wide volatility. In particular, Campbell, Lettau, Malkiel, and $\mathrm{Xu}$ (2001) point out that idiosyncratic volatility has trended upwards since the mid-1970's, while market-wide volatility has undergone temporary fluctuations but no trend increase. The findings of Campbell et al. suggest that increasing idiosyncratic volatility could have depressed corporate bond prices, and supported corporate equity prices, during the past few decades and during the late 1990's in particular.

The relevance of increasing idiosyncratic volatility is illustrated in Figure 2. This figure plots the average yield spread on A-rated corporate bonds, as reported by the credit rating agency Standard and Poor's (S\&P), from January 1965 through December 1999. It also plots a six-month backward moving average of idiosyncratic volatility, calculated from monthly cross-sectional data on individual stock returns by Goyal and Santa-Clara (2001). The two series display a common upward trend and substantial correlation in their movements at intermediate frequencies; the correlation of the levels of the two series is about 0.7 . The total volatility of a typical individual firm behaves in a similar fashion. The volatility of the market index, by contrast, has no upward trend and is much less closely related to the $\mathrm{S} \& \mathrm{P}$ corporate bond yield spread, with a correlation of only about $0.1 .^{1}$

The purpose of this paper is to measure the causes of variation, across companies and over time, in corporate bond yield spreads. Specifically, we evaluate the volatility effect while controlling for composition effects, the demand for the liquidity provided by Treasury bonds, and special features of corporate bonds. We first study corporate bond pricing in a large panel dataset, the Fixed Income Securities Database (FISD) on corporate bond characteristics matched to the National Association of Securities Commissioners (NAIC) database on bond transactions in the period 1995-99. We present new evidence that equity volatility explains as much variation in corporate credit spreads as do credit ratings. Controlling for general factors such as the reference Treasury rate, issue size, years to maturity, and time-series dummies, we find that equity volatility and credit ratings each explain about a third of the variation in corporate bond yield spreads. This finding is robust to the use of issuer fixed effects. We also explore the longer-term time-series behavior of corporate bond yields, as summarized by S\&P and Moody's yield indexes, and find that movements in idiosyncratic volatility help to explain these movements in average yields over time.

There is a large theoretical literature on the pricing of corporate bonds. This literature distinguishes between "structural" and "reduced form" models. In structural models, a firm is assumed to default when the value of its liabilities exceeds 
the value of its assets, in which case bondholders assume control of the company in exchange for its residual value. Black and Scholes (1973), Merton (1974), and Ingersoll (1977) are some of the classic papers in this area. More recently, Longstaff and Schwartz (1995) argue that the corporate yield spread should vary inversely with the benchmark Treasury yield, and they find evidence to support this prediction. CollinDufresne and Goldstein (2001) develop a structural model in which a firm can issue new debt, thereby increasing the risk of default and lowering the recovery rate in the event of default.

A difficulty with the structural approach is that investment-grade corporate bonds very rarely default. Elton, Gruber, Agrawal, and Mann (2001) argue on this basis that expected default can account for only a small part of the yield spread for investment-grade corporate over Treasury bonds, while state taxes (which are payable on corporate interest but not on Treasury interest) are relatively much more important. Huang and Huang (2000) reach a similar conclusion.

Reduced form models, by contrast, assume exogenous stochastic processes for the default probability and the recovery rate. These models can allow for premia to compensate investors for illiquidity and systematic credit risk. They can be fit econometrically to data on swap spreads and corporate bond yields (Jarrow and Turnbull (1995), Duffie and Singleton (1997, 1999), Duffee (1999), Liu, Longstaff, and Mandell (2000)). The added flexibility of the reduced-form approach allows default risk to play a somewhat greater role in the pricing of corporate bonds.

Our paper undertakes a less structured econometric analysis, asking what observable variables are correlated with corporate bond yields cross-sectionally and over time. There are several other recent papers in a similar spirit. Collin-Dufresne, Goldstein, and Martin (2001) find that a single unobserved factor, common to all corporate bonds, drives most variation in credit spread changes. Kwan (1996) shows that changes in a firm's stock price are negatively correlated with contemporaneous and future changes in the yields of its bonds. Duffee (1998) shows that yield spreads vary more strongly with benchmark Treasury rates for callable bonds than for noncallable bonds. But these papers have done little to explore the effect of equity volatility on the cross-sectional variation, long-term time-series behavior, or recent movements of corporate yield spreads. Our paper attempts to fill this gap in the academic literature. ${ }^{2}$

The remainder of the paper is organized as follows. Section I describes our panel data and the restrictions we impose on it. This section also examines trends in 
corporate bond spreads between 1995 and 1999. We find that, even after considering bonds without option-like features, credit spreads have been rising. However, this widening is not as large as would appear from the indexes produced by the credit rating agencies.

Section II links our data with equity and accounting data to investigate the link between equity volatility and corporate yield spreads. We present evidence that rising equity volatility dramatically raises the cost of borrowing. This effect is robust to a choice of a market model to define idiosyncratic volatility, the use of issuer fixed effects, and several other specification choices. This section also shows that the effect of volatility on corporate yield spreads is much stronger than would be predicted by the simple structural model of Merton (1974). Thus our results pose another challenge to theorists; not only are corporate yield spreads higher on average than would be predicted by the Merton model, they are also more sensitive to movements in equity volatility.

Section III returns to the time-series data, using an updated version of the idiosyncratic volatility series of Campbell et al., provided to us by Goyal and Santa-Clara (2001). We show that equity volatility helps to explain the movements of corporate yield spreads over the past several decades, and particularly in the late 1990's. Section IV concludes.

\section{Data description}

Our data come from the Fixed Investment Securities Database (FISD) and National Association of Insurance Commissioners (NAIC) transactions data. The FISD database contains issue- and issuer-specific variables such as callability, credit ratings, and sector, on all U.S. corporate bonds maturing in 1990 or later. The NAIC database consists of all 1995-1999 transactions by life insurance, property and casualty insurance, and Health Maintenance Organization (HMO) companies as distributed by Warga (2000). This database is an alternative to the no longer available Warga (1998) database used by Blume, Lim, and Mackinlay (1998), Collin-Dufresne, Goldstein, and Martin (2001), Duffee (1998), Elton, Gruber, Agrawal, and Mann (2000, 2001), and Hecht (2000).

Table I provides evidence on the representativeness of our transactions database. According to the Flow of Funds accounts published by the Federal Reserve, insurers comprise about one-third of the corporate bond market. Other important holders 
include foreign residents (15 to 20\%), households (15\%), pension and retirement funds (15\%), mutual funds (5 to 10\%), and commercial banks (5\%).

Table II summarizes the characteristics of corporate bond issuers as reported in the Flow of Funds accounts. We restrict our sample to fixed-rate US dollar bonds in the industrial, financial, and utility sectors that are non-callable, non-puttable, nonsinking fund, and non-convertible. To ensure that we consider bonds backed solely by the creditworthiness of the issuer, we exclude issues with asset-backed and creditenhancement features. While this last restriction eliminates almost one-quarter of corporate debt issues as shown in Table II, the yield spread on asset-backed bonds represents the creditworthiness of the collateral rather than the creditworthiness of the issuer. As such, we must exclude these issues.

Additionally, we only consider bonds whose average Standard and Poor's and Moody's credit rating lies between AA (Aa) and BBB (Baa). For bonds rated by only one of S\&P or Moody's, we use that agency's credit rating. We eliminate AAA (Aaa) bonds because the NAIC data for these issues appear particularly problematic. For instance, in 1995 our data show the average spread for medium-term (7-15 year) AAA-rated bonds as 109 basis points above the closest benchmark treasury, which is higher than the 100 basis point spread for A-rated bonds. This problem is even more acute in the financial sector, where in 1995 and 1996 the data suggest that AAA-rated bonds yielded roughly 30 basis points more than BBB-rated bonds. Elton, Gruber, Agrawal, and Mann (2000, 2001) found similar problems with AAA-rated bonds in their dataset. These authors also remove AAAs from their samples.

We eliminate non-investment grade (high-yield) debt because insurance companies often limit, or altogether prohibit, their purchase of these issues. Additionally, for insurance companies in our sample, the National Association of Insurance Commissioners' Securities Valuation Office requires a modest reserve ratio of $1 \%$ for AAA-rated bonds and $2 \%$ for $\mathrm{BBB}$ or better-rated bonds, but this reserve ratio jumps to $5 \%$ for BB (non-investment grade) debt. Since yield spreads are set by the market as a whole, which does not face NAIC reserve requirements, the spread on non-investment grade debt is particularly unattractive to insurance companies. Non-investment grade transactions in our database are likely to be unrepresentative of the general market.

As a final data screen, we eliminate the top and bottom one percent of spreads from our analysis to reduce apparent error in the NAIC data. ${ }^{3}$ Removing all bonds with special features (call, put, sinking fund, asset-backed, convertible), floating rate 
coupons, non-investment grade bonds, and bad data leaves us with approximately 52,000 different bond-month transactions.

\section{A. Summary statistics}

We calculate the yield to maturity on each bond in the sample and its spread over the closest benchmark U.S. treasury in a particular month. For the benchmark Treasuries, we use the CRSP Fixed Term indexes, which provide monthly yield data for notes and bonds of $1,2,5,6,10,20$, and 30 target years to maturity. Implicitly, we are assuming that each transaction occurs at the end of the month, when the CRSP Fixed Term indexes are published, but this should have little impact on the measured spread.

Table III summarizes the mean spread each year for the industrial, financial, and utility sectors, and for an aggregate of all three sectors. Following Duffee (1998), we also group the bonds by maturity, classifying them as short-term if they have 2-7 remaining years to maturity, medium-term if they have 7-15 remaining years to maturity, and long-term if they have 15-30 remaining years to maturity. We report results by credit rating, using the $\mathrm{S} \& \mathrm{P}$ rating scheme for notational convenience; thus we record a Moody's Aaa rating as AAA, Aa as AA, and Baa as BBB.

Table III shows that financials have the highest yield spreads, about 10 basis points higher than all sectors for medium-term bonds and 20 basis points higher for long-term bonds. There is no consistent pattern in the relative spreads on utilities and industrial bonds. Across sectors, A-rated bonds tend to yield about 20 basis points higher than AAs, and BBB-rated bonds yield 30 to 60 basis points higher than As. Yield spreads are considerably higher in 1998 and 1999 than in earlier years.

It is important to have a sense of the number of transactions in each category in our sample. We have 22,629 short-term, 14,503 medium-term, and 6,288 long-term transactions. About half the transactions in this sample are on bonds with an A credit rating and 30 to 40 percent on bonds with a BBB credit rating. The financial sector has the most transactions, and the utility sector the least. There are only 42 AA long-term utility transactions in the sample, most likely because utilities often issue bonds with call provisions.

It is interesting to compare our data with the average corporate yield spreads reported by S\&P and Moody's. To set the stage, in Figures 3 and 4 we plot average spreads reported by the two credit rating agencies over the entire period from January 
1965 through December 2000. We plot the series for four different credit ratings: AAA, AA, A, and BBB. The S\&P spreads in Figure 3 and the Moody's spreads in Figure 4 move in a similar fashion, with a noticeable tendency to increase when the stock market is weak and/or volatile, as in the mid-1970's, the early 1980's, and the period around the stock market crash of 1987. However, S\&P reports higher yield spreads than Moody's during the 1990's and therefore S\&P spreads show a stronger tendency to increase over the 1965-2000 period. This is partially accounted for by S\&P's greater weight on bonds issued by industrial companies.

In Figure 5, we directly compare the spreads implied by our subset of the NAIC data with the spreads reported by the rating agencies over the period since 1995 covered by the NAIC data. To make the figure easier to follow, we only plot A-rated bond spreads, but the results are similar for other rating categories. Here again we see that the Standard and Poor's index is often higher than the Moody's index, on the order of 80-100 basis points in late 1995-96 and 30-50 basis points in late 1998-99. Our NAIC spreads are lower overall, which makes sense because the rating agencies include debt with callable features and we do not. Adding transactions for bonds with callable features back into the NAIC data brings our spreads slightly closer to the S\&P and Moody's indexes.

It is noteworthy that after the financial turmoil of the late summer of 1998, yield spreads in the NAIC data declined to pre-crisis levels by February 1999, whereas the rating agency spreads did not fall significantly. We do not have a good explanation for this; the exclusion of callable features from our NAIC series seems to account for only a small portion of the discrepancy. We leave further exploration of this topic to future research.

\section{Equity volatility and the cross-section of corporate bond yields}

We now consider how an issuer's equity volatility influences the yield spread on its debt. In the simple framework of Merton (1974), corporate debt is a risk-free bond less a put option on the value of the firm's assets. The strike price equals the face value of the debt and reflects the limited liability of equityholders in the event of bankruptcy. A firm with more volatile equity is more likely to reach the boundary condition for default. Investors, recognizing this risk, should require additional compensation in the form of a higher yield spread over the riskfree rate. Importantly, this is true even if investors are risk-neutral or default risk is idiosyncratic. Volatility affects the 
spread by changing the expected payoff on corporate debt, even if it does not change the expected return or risk premium on the debt.

To explore this effect we use the NYSE, AMEX, and NASDAQ CRSP daily stock files for equity data and the COMPUSTAT annual full-coverage, industrial, and research files for accounting data. To ensure comparability of data, we adjust the COMPUSTAT fiscal year to the relevant calendar year. For each transaction, we consider the equity data for the 180 days prior to (not including) the bond trade and accounting data for the previous calendar year. This procedure ensures that all data are known to the market when a bond purchase or sale takes place. From our initial subset of the NAIC database, approximately 30,000 transactions are from publicly traded companies with available CRSP data in the transaction month. Further restricting to available COMPUSTAT data leaves us with about 22,000 transactions.

We run our regressions both with and without the credit rating on each bond. If both Moody's and Standard and Poor's rated an issue on a given transaction date, we use the average rating. If only Moody's or Standard and Poor's rated an issue, we consider that agency's rating.

We also consider accounting data because the meaning of a bond's credit rating is somewhat unclear. If credit ratings predict yield spreads, this tells us that credit rating agencies use relevant information effectively, but it tells us nothing about what information is relevant because only credit rating agencies know exactly what goes into a rating. If one is interested in the mapping from firm characteristics and market conditions to bond yields, it is more appropriate to consider the objective data that might go into a credit rating, such as financial leverage and other accounting ratios.

Specifically, we consider four accounting variables: pretax interest coverage, operating income to sales, long-term debt to assets, and total debt to capitalization. ${ }^{4}$ These are similar to the measures used in Blume, Lim, and Mackinlay (1998), CollinDufresne, Goldstein, and Martin (2001) and earlier papers (Pinches and Mingo (1973), Pogue and Soldofsky (1969)). High levels of the first two variables indicate financially healthy firms and are likely to produce a low yield spread. High levels of the second two variables indicate highly levered firms and imply a high yield spread. To conform with the underlying theory of contingent claims valuation, total debt to capitalization uses market (not book) value of equity as of one day prior to the bond transaction date.

Rather than measure interest coverage continuously, we break it into four groups. 
Blume, Lim, and Mackinlay (1998) argue that a change in interest coverage from 4 to 6 (the means for BBB- and A-rated bonds, respectively) may result in a bond upgrade. A similar change from 20 to 22 would likely have no effect since the mean interest coverage for AAA-rated bonds is 13 . We therefore anticipate that particularly low pretax interest coverage may convey more information about the risk of an issuer than high interest coverage. To account for this possibility, we create dummy variables to indicate whether pretax interest coverage is less than 5 , between 5 and 10 , between 10 and 20, or greater than 20 .

To summarize firm-level risk and return, we compute the mean and standard deviation of daily excess returns, relative to the CRSP value-weighted index, for each firm's equity over the 180 days preceding (not including) the bond transaction date. Thus we avoid estimating betas for individual firms on the market index, effectively imposing a beta of one (and an alpha of zero) in the market model. Campbell, Lo, and MacKinlay (1997, p. 156) call this a "market-adjusted-return" model. We also include the mean and standard deviation of daily market returns, where the market is defined as the CRSP value-weighted index over the same 180 days. We expect the standard deviation of daily excess returns to have a positive effect on yield spreads; the standard deviation of daily index returns may also have a positive effect to the extent that it influences the total standard deviation of firm returns. We expect recent past stock returns to have a negative effect on yield spreads, as documented by Kwan (1996).

We use the closest benchmark Treasury rate and the difference between the 10and 2-year Treasury rates to describe the level and slope of the term structure, respectively. Longstaff and Schwartz (1995) argue that the expected sign on the level of the Treasury rate is negative because a higher interest rate increases the drift of the risk-neutral process for the value of the firm. In turn, this lowers the riskneutral probability of default and the corporate bond yield spread. Collin-Dufresne, Goldstein, and Martin (2001) reason that the slope of the term structure provides a measure of uncertainty about the economy, as well as an expectation of future short rates.

We want to control for liquidity effects on corporate bonds relative to Treasury bonds. This is particularly important because the Asian, Long Term Capital Management (LTCM), and Russian financial crises all occur during our sample period. To proxy the demand for liquidity, we include the difference between the 30-day Eurodollar and Treasury yields. The expected coefficient on this variable is positive, 
as a wider spread indicates a flight to quality or liquidity which will increase the required compensation for holding corporate bonds (Longstaff (2001)). To proxy for cross-sectional differences in corporate bond liquidity, we include issue size in the regression. Following Elton, Gruber, Agrawal, and Mann (2000), we also include the coupon rate because bonds with higher coupons are taxed more throughout the life of the bond, making them less desirable than bonds with lower coupons. Finally, we include twelve month dummies (January through December) to capture seasonal effects.

Our regressions proceed as follows. First, we report the results of ordinary least squares (OLS) regressions treating each transaction as an independent observation. Second, we remove pure cross-sectional variation in issuer quality by estimating fixed effects for each bond issuer. Third, we remove the time-series variation in average yields by replacing the twelve month dummies (January through December) with sixty monthly time dummies (January 1995 to December 1999). Once we have demonstrated that equity volatility helps to determine corporate bond yield spreads in each framework, we consider interaction effects and evaluate the robustness of the results in the next subsection.

Table IV reports the results of ordinary least squares (OLS) regressions. We report the results for all sectors but reach similar conclusions for each individual sector. Odd numbered columns report results without equity volatility; even numbered columns repeat the regressions with equity volatility. One should interpret the coefficient estimates as follows. In column 2, if the standard deviation of daily excess returns rises by one percentage point, then the corporate bond spread rises by 222 basis points. If the standard deviation of annualized excess returns rises by one percentage point, then the corporate bond spread rises by $222 / \sqrt{252}=14$ basis points. Similarly, if the mean daily (annualized) index return increases by one percentage point, then the corporate bond spread falls by 105 (7) basis points.

Several observations are notable. First, including equity volatility raises the adjusted R-squared by 6 to 10 percentage points (even numbered columns minus odd numbered columns). The coefficient on the standard deviation of excess returns is highly significant with a t-statistic of 34-40. Both results suggest that volatility is an important determinant of corporate bond yield spreads.

Second, equity volatility matters at least as much as credit ratings. A regression of yield spreads on equity volatility (column 2) results in an adjusted R-squared nearly 2 percentage points higher than a regression of spreads on credit ratings (col- 
umn 3). This observation makes sense because equity volatility can reflect both continuous information that distinguishes bonds with the same credit rating, and recent information that may not yet be reflected in a bond's credit rating.

Third, equity volatility and credit ratings may be used in tandem to better explain bond spreads. Including both variables in the regression (column 4) results in an adjusted R-squared 5 percentage points higher than volatility alone and 7 percentage points higher than credit ratings alone. This result suggests that credit ratings capture some information that is not contained in volatility.

Fourth, credit ratings explain more of the yield spread than accounting data (columns 3-6). This is not surprising because a credit rating is designed to convey information not contained elsewhere. Additionally, our accounting data is updated only at the close of the previous calendar year, while our credit ratings may be updated at any time. We note that total debt to capitalization results in the wrong sign (negative) in column 6.

Fifth, adding accounting variables on top of credit ratings (columns 7-8) does not meaningfully raise the adjusted R-squared over credit ratings alone. The accounting variables generally have the expected signs when significant, with the exception of pretax interest coverage, which takes the wrong sign (positive) in column 7.

Sixth, the estimated coefficient on the standard deviation of daily excess returns is much larger than the coefficient on the standard deviation of daily index returns. This might seem surprising, since what matters in a contingent claims model is the total risk of the firm. Note however that we include standard deviations, not variances, in the regression, so total risk does not equal the sum of idiosyncratic and market risk. Also, we are using lagged measures of risk to proxy for expectations of future risk. Campbell, Lettau, Malkiel, and Xu (2001) find that movements in idiosyncratic risk are more persistent than movements in market risk, which would imply that lagged idiosyncratic risk should receive a greater weight in predicting future risk. Finally, the regression includes other independent variables that are strongly correlated with market risk; for example, the closest benchmark Treasury and the standard deviation of daily index returns have a correlation of about $-2 / 3$.

The explanatory power of recent equity returns and volatility, as compared with credit ratings, makes good sense. All data going into a credit rating should be captured in the equity price. Equity markets reflect up-to-date information whereas credit ratings may be revised infrequently and with a lag. In the extreme, Ederington, 
Yawitz, and Roberts (1987) argue that investors fully anticipate rating changes and rating changes almost never affect bond returns. Since one might view equity as junior debt, where a dividend is paid only when the firm does not default, equity investors should take into account default probabilities, recovery rates, and relevant accounting ratios. From this standpoint, the only thing surprising about the link between equity volatility and bond spreads is that it has attracted so little attention from empirical researchers.

At this point we have shown that yield spreads vary directly with equity volatility across companies. If General Motors' (GM) equity is less volatile than Ford's, then GM faces a lower yield spread than Ford. We now consider the pattern within a single company. Within GM, is the yield spread on GM debt lower when GM's equity is less volatile?

The answer is yes, as reported in Panel A of Table V. Applying fixed effects to each of our 581 bond issuers, we find similar results to the basic OLS regressions. The coefficient on the standard deviation of daily excess returns is almost unchanged. The t-statistic is smaller but still highly significant, despite a marked increase in the coefficient and significance of the total debt to capitalization accounting variable. While not reported in this table, it is also noteworthy that equity volatility continues to explain more of the yield spread than do credit ratings alone.

One potential objection is that the regressions may simply be picking up timeseries variation in the data. To address this concern, Panel B of Table V considers the same regressions but replaces the seasonal dummies (February to December) with monthly time dummies between February 1995 and December 1999. Once again, the results are substantially similar. In this table we include issuer fixed effects, but we find similar results if we exclude them.

The monthly time dummies represent unexplained time-series variation in average corporate yield spreads. If we compare the monthly time dummies from a regression of yield spreads on credit ratings and accounting variables (Panel B of Table V, column 1) with the dummies from a regression that also includes equity volatility (Panel B of Table V, column 2), we find that the latter dummies have a mean closer to zero and a smaller standard deviation (20 basis points rather than 22). This shows that equity volatility captures some of the time-series variation that otherwise would be left to dummy variables.

Finally, to ensure the reasonableness of our standard errors, we run a cross- 
sectional regression each month and calculate Fama-MacBeth (1973) estimates and standard errors. The coefficient on the standard deviation of daily excess returns over the preceding 180 days is 126 with a t-statistic of 13 , so our results remain highly significant with this conservative approach to estimation and inference.

\section{A. Interaction effects}

We have demonstrated that equity volatility helps to determine corporate bond yield spreads in the cross-section. There remains the question of how the firm's capital structure interacts with other determinants of the yield spread. We consider three interactions: total debt to capitalization with equity volatility, long-term debt to assets with equity volatility, and long-term debt to assets with the closest benchmark Treasury rate.

The ratios of total debt to capitalization and long-term debt to assets may influence the strength of the volatility effect because investors may regard a company with almost no debt as unlikely to default even when the issuer's equity is highly volatile. Simply put, a firm is unlikely to go bankrupt over a small amount of debt. On the other hand, a company with relatively high debt and particularly volatile equity is at particularly high risk of bankruptcy, and this risk should be reflected in a higher yield spread.

The benchmark Treasury rate is also relevant for a firm with long-term debt. A higher Treasury rate increases the nominal return on potential investments, but the nominal interest cost of long-term borrowing stays the same because the firm already has issued bonds at a fixed rate of interest. Equivalently, a higher Treasury rate reduces the market value of liabilities more than the market value of assets. From either perspective, an increase in the Treasury rate should reduce the probability of default for a firm with high long-term debt. The effect of the Treasury rate should be weaker for a firm with medium- and short-term liabilities, since a higher Treasury rate raises the cost of rolling over short-term debt and therefore has little effect on the market value of the firm's liabilities.

Table VI explores these interaction effects using OLS. We break the interaction variables into approximate quartiles: less than 10\%, 10 to $25 \%, 25 \%$ percent to onethird, and greater than one-third. While the relationship is not monotonic, it does appear that equity volatility is more important for firms with high long-term debt to assets and high total debt to capitalization. Similarly, the impact of the Treasury rate is stronger on firms with high ratios of long-term debt to assets. Even allowing 
for interaction effects, equity volatility continues to be an important determinant of bond yield spreads, as evidenced by a higher adjusted $R^{2}$ statistic in columns 2 and 4 . These results are not sensitive to the inclusion of issuer fixed effects or time dummies.

\section{B. Robustness checks}

We now address the robustness of our findings. To do so, we consider changes in the definition of idiosyncratic volatility and the number of days used to calculate it. For each bond transaction, we estimate a market model on the preceding 180 calendar days of the issuer's equity. From this, we multiply the daily index return by beta (dropping the implicit assumption of the earlier market-adjusted-return model that beta equals one) and calculate the idiosyncratic return and its standard deviation. We re-run this procedure using 90, 270, and 360 calendar days of the issuer's equity.

Table VII shows that our results are robust to these changes. While we report the OLS results for equity volatility, credit ratings, and accounting data together (analogous to column 8 of Table IV), we find similar results for the various combinations presented in earlier tables. Idiosyncratic risk takes on a t-statistic of about 35-40 in the OLS regressions, 25-30 in the issuer fixed-effects regressions, and 10 in the issuer fixed-effects regressions with monthly time dummies. The coefficient on equity volatility using 180 or more days of data exceeds that of 90 days, suggesting that a fairly long time window is needed to measure the volatility that is relevant to corporate bond investors.

As a final test of the results, we follow the procedure of Elton, Gruber, Agrawal, and Mann (2001) to eliminate coupon effects from corporate bond yields. Elton et al. suggest that, because arbitrage arguments hold with zero-coupon spot rates, it makes sense to model zero-coupon yields from a coupon-paying corporate bond and the corresponding Treasury. This modeling procedure involves separating out bonds by month, sector, and credit rating to fit 540 yield curves (60 months x 3 sectors x 3 credit ratings), using the estimation method of Nelson and Siegel (1987) outlined in Appendix A.

For each month, we estimate the price of a corporate bond as fit by the NelsonSiegel procedure for that bond's sector and credit rating. Following Elton et al., we compare this price with the actual price, eliminating observations where the difference is $\$ 5$ or more. We then transform prices into yields to maturity and calculate the actual yield less the estimated yield. Within each sector and credit rating, we regress this yield difference on equity volatility, plus or minus credit ratings, and state 
variables. The expected sign on a plus (minus) credit rating is negative (positive). For example, a financial sector A+ bond should have a lower yield spread than the spread that is fitted to all financial bonds with $\mathrm{A}+, \mathrm{A}$, and $\mathrm{A}$ - ratings.

Panel A of Table VIII presents the results. The drastic reduction in R-squared is not surprising since we have subtracted out all variation across sectors and credit ratings and over time by calculating deviations from the fitted Nelson-Siegel yields. Idiosyncratic volatility is most significant for A- and BBB-rated industrials, but it also affects A-rated financial bonds. The regressions for these bonds (columns 2, 3, and 5) also have the best fit overall as indicated by their F-statistics.

To see how much difference the Nelson-Siegel method makes, Panel B of Table VIII regresses actual bond yield spreads for each sector and credit rating against the variables in Panel A. We include sixty monthly time dummies to account for the subtraction of time-series variation in the Nelson-Siegel estimation procedure. Our results are similar. The t-statistics on equity volatility are most significant in columns 2, 3, and 5, as are the F-statistics for the entire regression. This leaves us with two additional results. First, the equity volatility effect is robust to the estimation of a zero-coupon corporate bond yield curve. Second, it is not clear that an analysis of corporate bond yield spreads must measure spreads in relation to a zero-coupon curve. We obtain very similar results whether we use the Nelson-Siegel methodology or not.

To summarize, our analysis suggests that equity volatility is an important determinant of corporate bond yield spreads. In the cross-section, volatility can explain as much of the yield spread as can credit ratings. This finding continues to hold when we include fixed effects for each bond issuer and when we control for monthly time-series variation. Equity volatility is particularly important for firms with a high ratio of long-term debt to assets. These results are robust to the use of a market model with an estimated beta, the use of a longer or shorter time window to estimate volatility, and the use of the Nelson-Siegel method to adjust for the slope of the term structure.

\section{The volatility effect and contingent claims analysis}

At this point, one might ask how our results compare with the predictions of a standard contingent claims model. To answer this question, we turn to Merton (1974), who derives a formula for the credit spread based on an issuer's leverage, volatility, a bond's years to maturity, and the riskfree rate. We make the simplifying 
assumption that the volatility of a firm is determined solely by its equity (not debt). Then, using the mean value of the input parameters for each of our 581 issuers, we compute the partial derivative of the credit spread with respect to equity volatility. Appendix B outlines the estimation procedure.

A key step in applying the Merton contingent claims model is deriving the volatility of an issuer's total value from the volatility of its equity. We use two extremes, neither realistic, to obtain a range of predictions of the model. We use these extremes simply to provide a crude comparison between our results and those of structural models, in the hope that this will stimulate further research on the subject. Jones, Mason, and Rosenfeld (1984) link issuer volatility to equity volatility in a more careful manner.

First, we calculate asset volatility under the assumption that corporate debt is riskless (an assumption that is inconsistent with a model of risky debt). Using this procedure, we are able to explain about 10 percent of the actual change in spread due to equity volatility. For each 1 percentage point increase in annualized total volatility, the contingent claims model suggests a mean increase in yield spread of 1.64 basis points. Regressing the actual credit spread on annualized total volatility in the NAIC dataset gives a coefficient of 16.00. For comparison, the contingent claims model explains about 27 percent of the level of actual spreads in our database (a theoretical mean of 39 basis points, compared to an actual mean of 141 basis points).

Alternatively, we assume that corporate debt is very risky, setting the proportional volatility of an issuer's bonds equal to the volatility of its stock. Using this procedure, we are able to explain about 22 percent of the actual change in spread due to equity volatility (a contingent claims partial derivative of 3.46 divided by a regression coefficient of 16.00). For comparison, the contingent claims model now overstates the level of actual spreads, with a theoretical mean of 168 basis points compared to the actual mean of 141 basis points.

These results leave us with a puzzling mismatch between our econometric results and the predictions of a standard structural model. An important topic for future research will be to develop structural models in which equity volatility has a larger effect on corporate bond yields, perhaps through jumps in firm value or a risk premium on systematic credit risk. 


\section{Equity volatility and the time-series of corporate bond yields}

We now explore the longer-term time-series behavior of corporate bond yield spreads, as summarized by the Standard and Poor's and Moody's yield indexes. We find that movements in idiosyncratic volatility help to explain these movements in average yields over time. Using an updated version of the idiosyncratic volatility series of Campbell, Lettau, Malkiel, and Xu (2001), provided to us by Goyal and Santa-Clara (2001), we calculate a six-month moving average of market and idiosyncratic risk between January 1963 and December 1999. This moving average proxies for the 180 days of firm-level equity data used in the previous section.

Our motivation is straightforward. First, our cross-sectional data set is limited in that it restricts our analysis to the years 1995-99. The importance of equity volatility may be an aberration of the late 1990s that does not apply to earlier years. Second, Campbell et al. point out that idiosyncratic volatility has trended upwards since the mid-1970's, while market-wide volatility has undergone temporary fluctuations but no trend increase. These findings suggest that increasing idiosyncratic volatility could have depressed corporate bond prices yet supported equity prices during the late 1990's. A longer time-series of data allows us to analyze this hypothesis.

Table IX reports regressions of the Standard and Poor's and Moody's yield spread indexes against equity volatility and macroeconomic variables. To control for aggregate leverage, we use the aggregate ratio of corporate bonds to assets as reported by the Flow of Funds accounts. As a measure of liquidity, we include monthly debt turnover in U.S. Government securities, provided to us by Fleming (2000)..$^{5}$

Panels A and B consider the results for S\&P and Moody's A-rated corporate bonds, respectively. (We find similar results for an equal weighted index of AAA, $\mathrm{AA}, \mathrm{A}$, and BBB-rated issues.) The coefficient on idiosyncratic risk is smaller in the time series than in our earlier cross-sectional regressions, but is significant in column 2 for both indexes, with a t-statistic of about 19 for S\&P and 4 for Moody's. When we add aggregate leverage and debt turnover to the regression (column 3), debt turnover has the wrong sign (positive), and only the S\&P coefficient remains significant. Recalling the upward trend of S\&P data in Figure 3, it is interesting to note that the adjusted $\mathrm{R}$-squared on the regression without equity volatility is about 30 percentage points higher for S\&P than for Moody's (column 1). With equity volatility, the adjusted $\mathrm{R}$-squared for $\mathrm{S} \& \mathrm{P}$ is $50-55$ percentage points higher than for Moody's (columns 2 and 3). 
Figure 6 puts the results of column 2 in graphical perspective for A-rated S\&P corporate bonds. An in-sample prediction of equity volatility captures the broad trends of actual yield spreads, performing particularly well in the 1970s and early 1980s. Over our 37-year horizon, the root mean squared error with equity volatility is about 12 basis points lower than without equity volatility (33 versus 45 basis points). Neither series performs particularly well in the late 1990s, although the insample prediction with equity volatility performs better than the prediction without volatility.

In Figure 7, we repeat the column 2 regression of S\&P A-rated yield spreads, this time for 1963-94. We then predict out-of-sample yield spreads for 1995-99 with and without equity volatility, plotting them against actual A-rated yield spreads. The prediction of yield spreads with equity volatility is uniformly higher than the prediction without volatility, resulting in one-half of the root mean squared error (34 versus 67 basis points). Although the series without volatility performs better for the one year between mid-1996 and mid-1997, the series with volatility captures the upswing in credit spreads beginning August 1998 and remains high through the end of 1999. Overall these results suggest that equity volatility is an important factor in understanding the movements in aggregate corporate bond yield spreads, both over the last few decades and in the late 1990s.

\section{Conclusion}

In this paper we have documented a link between rising idiosyncratic equity risk and increasing yields on corporate bonds relative to Treasury bonds. These two phenomena have been noted before, but there has been little research on the empirical connection between them.

Our analysis has proceeded as follows. First, we have compared the average yield spreads reported by Standard and Poor's and Moody's with a panel dataset on corporate bond transactions between 1995 and 1999. We have found that credit spreads widened in the late 1990s, although less in the panel dataset than in the spread indexes reported by the rating agencies.

Second, we have provided evidence that idiosyncratic equity volatility is directly related to the cost of borrowing for corporate issuers. Our data suggest that volatility can explain as much cross-sectional variation in yields as can credit ratings, and that

volatility contributes explanatory power even in the presence of credit ratings. These 
findings are robust to the inclusion of fixed effects for each bond issuer, the inclusion of monthly time dummies, the market model used to define idiosyncratic returns, the time window used to measure volatility, and the estimation of a zero-coupon term structure to control for maturity effects.

Third, using Standard and Poor's and Moody's corporate bond yield indexes between 1963 and 1999, we have shown that aggregate corporate yield spreads widen during periods of higher idiosyncratic risk. Thus equity volatility helps to explain not

only recent movements in corporate yield spreads, but also their longer-term upward trend.

This paper has used a relatively unstructured econometric approach to explore the effect of equity volatility on the cost of corporate borrowing. The effect appears to be much stronger than can be explained by the standard structural model of Merton (1974). An important challenge for future research will be to develop theoretical models that can account for the strong empirical relationship between equity volatility and corporate bond yields.

\section{Appendix A. Estimating the zero-coupon yield curve}

Following Elton, Gruber, Agrawal, and Mann (2001), we adopt the procedure of Nelson and Siegel (1987) to estimate the zero-coupon yield curve. For each month, we fit the following equations to all bonds in a sector-credit rating combination:

$$
\begin{gathered}
B(t)=\exp \{-r(t) \cdot t\} \\
r(t)=\beta_{0}+\left(\beta_{1}+\beta_{2}\right)\left(\frac{1-\exp \left\{-\beta_{3} t\right\}}{\beta_{3} t}\right)-\beta_{2} \exp \left\{-\beta_{3} t\right\}
\end{gathered}
$$

where $B(t)$ is the present value of a payment to be received $t$ periods in the future, $r(t)$ is the spot rate, and $\beta_{0}, \beta_{1}, \beta_{2}$, and $\beta_{3}$ are parameters of the model.

We estimate 540 corporate zero-coupon yield curves (60 months x 3 sectors $\mathrm{x}$ 3 credit ratings) and 60 Treasury zero-coupon curves over the period January 1995 through December 1999. We define the zero-coupon yield spread as the difference between the corporate and Treasury spot rates. As described in the text, we regress 
the difference between the actual yield spread and the estimated yield spread on the variables in Table IX.

\section{Appendix B. Estimating the volatility effect under contingent claims analysis}

Merton (1974) derives the following formula for the yield spread of a firm that issues risky debt:

$$
R(\tau)-r=-\frac{1}{\tau} \ln \left\{\Phi\left[h_{2}\left(d, \sigma_{V}^{2} \tau\right)\right]+\frac{1}{d} \Phi\left[h_{1}\left(d, \sigma_{V}^{2} \tau\right)\right]\right\}
$$

where $\Phi(x)$ denotes the standard normal cumulative distribution function evaluated at $x, R(\tau)$ the yield to maturity on the bond provided the firm does not default, $r$ the riskfree rate, $\tau$ the number of years until maturity, and $\sigma_{V}^{2}$ the volatility of the firm's assets. Also, $h_{1}\left(d, \sigma_{V}^{2} \tau\right)=-\left(\sigma_{V}^{2} \tau-\ln (d)\right) / 2 \sigma_{V} \sqrt{\tau}, h_{2}\left(d, \sigma_{V}^{2} \tau\right)=$ $-\left(\sigma_{V}^{2} \tau+\ln (d)\right) / 2 \sigma_{V} \sqrt{\tau}$, and $d=D \exp (-r \tau) / V$.

$D$ represents the face value of the firm's liabilities. The firm defaults at time $T$ $(\tau=0)$ if liabilities exceed the value of the firm. Should the firm default, bondholders take over the firm and equityholders receive nothing.

The model leaves open the issue of how to estimate $\sigma_{V}^{2}$. For the purpose of a rough comparison with our reduced form results, we choose to adopt a very simple framework with two extremes, neither of which is realistic.

First, we assume that the firm's debt is approximately riskless, so that its market value equals its face value. This assumption is inconsistent with a model of risky debt, but again, we are simply trying to obtain a basic comparison with our regressions. With the value of a firm $(V)$ equal to the market value of debt plus the market value of equity $(E)$, we have $d V=d E$. This implies that firm volatility is $\sigma_{E}=\sigma_{V}(1+D / E)$.

Second, we assume that the proportional volatility of the firm's debt is the same as that of its equity. We then have $\sigma_{E}=\sigma_{V}$.

We assume that $D$ equals the book value of liabilities (from Compustat), $E$ equals the market value of equity (from CRSP), and $\sigma_{E}$ the annualized standard deviation of total equity returns from the 180 days preceding a bond transaction. Using this 
framework, we estimate the change in yield spread due to a change in equity volatility. Taking the partial derivative of equation (B1) with respect to equity volatility gives:

$$
\frac{\partial[R(\tau)-R]}{\partial \sigma_{E}}=\frac{\sqrt{\frac{2}{\pi}}\left[\exp \left\{-\frac{1}{2}\left[h_{1}(\cdot)\right]^{2} \frac{\partial h_{1}(\cdot)}{\partial \sigma_{E}}\right\}+d \exp \left\{-\frac{1}{2}\left[h_{2}(\cdot)\right]^{2} \frac{\partial h_{2}(\cdot)}{\partial \sigma_{E}}\right\}\right]}{2 \tau\left(\Phi\left[h_{1}(\cdot)\right]+d \Phi\left[h_{2}(\cdot)\right]\right)}
$$

where:

$$
\begin{aligned}
& \frac{\partial h_{1}(\cdot)}{\partial \sigma_{E}}=-\frac{\sqrt{\tau}}{2\left(1+\frac{D}{E}\right)}-\frac{\left(1+\frac{D}{E}\right) \ln (d)}{\sigma_{E}^{2} \sqrt{\tau}} \\
& \frac{\partial h_{2}(\cdot)}{\partial \sigma_{E}}=-\frac{\sqrt{\tau}}{2\left(1+\frac{D}{E}\right)}+\frac{\left(1+\frac{D}{E}\right) \ln (d)}{\sigma_{E}^{2} \sqrt{\tau}}
\end{aligned}
$$

for the assumption of riskless debt, and

$$
\begin{gathered}
\frac{\partial h_{1}(\cdot)}{\partial \sigma_{E}}=-\frac{\sqrt{\tau}}{2}-\frac{\ln (d)}{\sigma_{E}^{2} \sqrt{\tau}} \\
\frac{\partial h_{2}(\cdot)}{\partial \sigma_{E}}=-\frac{\sqrt{\tau}}{2}+\frac{\ln (d)}{\sigma_{E}^{2} \sqrt{\tau}}
\end{gathered}
$$

for the assumption that $\sigma_{E}=\sigma_{V}$.

For all bond transactions of a given issuer, we take the mean value of $D, E, \sigma_{E}$, $\tau$, and $r$ (defined as the closest benchmark Treasury). Using these mean values, we estimate the partial derivative of the issuer's spread with respect to equity volatility, as discussed in the text. 


\section{References}

Black, Fischer and Scholes, Myron, 1973, The pricing of options and corporate liabilities, The Journal of Political Economy 81, 637-654.

Blume, Marshall E., Felix Lim, and Craig A. Mackinlay, 1998, The declining credit quality of U.S. corporate debt: Myth or reality? Journal of Finance 53, 13891413.

Campbell, John, Martin Lettau, Burton G. Malkiel, and Yexiao Xu, 2001, Have individual stocks become more volatile? An empirical explanation of idiosyncratic risk, Journal of Finance 56, 1-43.

Campbell, John, Andrew Lo, and Craig A. MacKinlay, 1997, The Econometrics of Financial Markets, Princeton University Press, Princeton, NJ.

Collin-Dufresne, Pierre, and Robert S. Goldstein, 2001, Do credit spreads reflect stationary leverage ratios? Journal of Finance 56, 1929-1957.

Collin-Dufresne, Pierre, Robert S. Goldstein, and J. Spencer Martin, 2001, The determinants of credit spread changes, Journal of Finance 56, 2177-2207.

Duffee, Gregory R., 1998, The relation between treasury yields and corporate bond yield spreads, Journal of Finance 53, 2225-2241.

Duffee, Gregory R., 1999, Estimating the price of default risk, The Review of Financial Studies 12, 197-226.

Duffie, Darrell, and Kenneth J. Singleton, 1997, An econometric model of the term structure of interest-rate swap yields, Journal of Finance 52, 1287-1321.

Duffie, Darrell, and Kenneth J. Singleton, 1999, Modeling term structures of defaultable bonds, The Review of Financial Studies 12, 687-720.

Ederington, Louis H., Jess B. Yawitz, and Brian E. Roberts, 1987, The informational content of bond ratings, Journal of Financial Research 10, 211-226.

Elton, Edwin J., Martin J. Gruber, Deepak Agrawal, and Christopher Mann, 2000, Factors affecting the valuation of corporate bonds, unpublished paper, New York University. 
Elton, Edwin J., Martin J. Gruber, Deepak Agrawal, and Christopher Mann, 2001, Explaining the rate spread on corporate bonds, Journal of Finance 56, 247-278.

Fama, Eugene F., and James D. MacBeth, 1973, Risk, return and equilibrium, The Journal of Political Economy 81, 607-636.

Fleming, Michael J., 2000, Financial market implications of the Federal debt paydown, Brookings Papers on Economic Activity 2, 221-251.

Goyal, Amit, and Pedro Santa-Clara, 2001, Idiosyncratic risk matters!, unpublished paper, UCLA.

Hecht, Peter, 2000, The cross section of expected firm (not equity) returns, unpublished paper, Harvard Business School.

Huang, Jingzhi and Ming Huang, 2000, How much of the corporate-Treasury yield spread is due to credit risk?, unpublished paper, Graduate School of Business, Stanford University.

Ingersoll, Jonathan E., 1977, A contingent-claims valuation of convertible securities, Journal of Financial Economics 4, 289-321.

Kwan, Simon H., 1996, Firm-specific information and the correlation between individual stocks and bonds, Journal of Financial Economics 40, 63-80.

Jarrow, Robert A., and Stuart M. Turnbull, 1995, Pricing derivatives on financial securities subject to credit risk, Journal of Finance 50, 53-85.

Jones, E. Philip, Scott P. Mason, and Eric Rosenfeld, 1984, Contingent claims analysis of corporate capital structures: An empirical investigation, Journal of Finance 39, 611-625.

Liu, Jun, Francis A. Longstaff, and Ravit E. Mandell, 2000, The market price of credit risk: An empirical analysis of interest rate swap spreads, unpublished paper, UCLA.

LJS Global Information Services, Inc., 2000, Fixed Investment Securities Database, Powell, Wyoming.

Longstaff, Francis A., 2001, The flight-to-liquidity premium in U.S. Treasury bond prices, unpublished paper, UCLA. 
Longstaff, Francis A., and Eduardo S. Schwartz, 1995, A simple approach to valuing risky fixed and floating rate debt, Journal of Finance 50, 789-819.

Merton, Robert C., 1974, On the pricing of corporate debt: The risk structure of interest rates, Journal of Finance 29, 449-470.

Nelson, Charles R., and Andrew F. Siegel, 1987, Parsimonious modeling of yield curves, Journal of Business 60, 473-489.

Pinches, George, E., and Kent A. Mingo, 1973, A multivariate analysis of industrial bonds ratings, Journal of Finance 28, 1-16.

Pogue, Thomas F., and Robert M. Soldofsky, 1969, What's in a bond rating? Journal of Financial and Quantitative Analysis 4, 201-228.

Warga, Arthur D., 2000, National Association of Insurance Commissioners Database, University of Houston, Houston, Texas.

Warga, Arthur D., 1998, Fixed income database, University of Houston, Houston, Texas. 


\section{Footnotes}

1. We note that average yield spreads reported by Moody's have a smaller upward trend and are about equally correlated with idiosyncratic volatility and market volatility. We discuss both the S\&P and Moody's data in more detail in sections I and III below.

2. The financial press has been more sensitive to the relation between equity volatility and corporate bond spreads. For instance, in October 2000, the Financial Times wrote, "The increased volatility in the equity markets is another sign of the rising risks faced by companies, and bond investors are starting to re-price their investments." (Chaffin, Joshua and Van Duyne, Aline, "Corporate bond crisis grows amid credit fears: Industrial groups worst hit as spreads widen in US and Europe," Financial Times: October 12, 2000, p. 25).

3. We explored several alternative cutoffs (0, 2, 5, 10, 20, and 25 percent) before deciding on the one percent screen. The results of the paper are not particularly sensitive to the exact screen used.

4. Similar to Blume, Lim, and Mackinlay (1998), our accounting variables are as follows, with Compustat item numbers in parentheses. Pretax interest coverage is the ratio of [operating income after depreciation (178) + interest expense (15)] to [interest expense (15)]. Operating income to sales is [operating income before depreciation (13)] to [net sales (12)]. Long-term debt to assets is [total long-term debt (9)] to [total assets (6)]. Total debt to capitalization is [total long-term debt (9) + debt in current liabilities (34) + average short-term borrowings (104)] to [total liabilities (181) + market value of equity (from CRSP)]. Each Compustat variable is obtained as of the end of the previous calendar (not fiscal) year. The market value of equity is obtained as of one day prior to the bond transaction date.

5. The Flow of Funds accounts report equity at market value, although debt is measured at book value. The definition of debt turnover is the daily average of the total volume of dealer transactions in U.S. Government securities, as reported to the Federal Reserve Bank of New York, relative to marketable debt. 
Table I. Holders of corporate debt, 1955-2000

\begin{tabular}{|c|c|c|c|c|c|c|c|}
\hline Year & $\begin{array}{c}\text { Total assets } \\
\text { (Billion USD) }\end{array}$ & $\begin{array}{l}\text { Insurance } \\
\text { companies }\end{array}$ & $\begin{array}{l}\text { Foreign } \\
\text { holders }\end{array}$ & $\begin{array}{l}\text { Household } \\
\text { sector }\end{array}$ & $\begin{array}{l}\text { Pension } \\
\text { and } \\
\text { retirement } \\
\text { funds }\end{array}$ & $\begin{array}{l}\text { Mutual } \\
\text { funds }\end{array}$ & $\begin{array}{c}\text { Commercial } \\
\text { banking }\end{array}$ \\
\hline 1955 & 60.8 & $63.0 \%$ & $0.7 \%$ & $8.2 \%$ & $17.3 \%$ & $0.8 \%$ & $3.5 \%$ \\
\hline 1960 & 91.8 & $54.3 \%$ & $0.7 \%$ & $11.6 \%$ & $24.9 \%$ & $1.4 \%$ & $1.5 \%$ \\
\hline 1965 & 123.1 & $52.0 \%$ & $0.7 \%$ & $7.5 \%$ & $32.4 \%$ & $2.1 \%$ & $1.0 \%$ \\
\hline 1970 & 204.3 & $40.5 \%$ & $1.3 \%$ & $14.4 \%$ & $31.6 \%$ & $1.7 \%$ & $1.5 \%$ \\
\hline 1975 & 336.4 & $35.0 \%$ & $1.4 \%$ & $18.7 \%$ & $30.6 \%$ & $1.7 \%$ & $2.8 \%$ \\
\hline 1980 & 507.6 & $39.9 \%$ & $7.3 \%$ & $5.9 \%$ & $33.5 \%$ & $1.7 \%$ & $2.1 \%$ \\
\hline 1985 & 883.1 & $35.6 \%$ & $14.3 \%$ & $8.8 \%$ & $23.2 \%$ & $2.6 \%$ & $3.5 \%$ \\
\hline 1990 & 1705.7 & $38.5 \%$ & $12.7 \%$ & $12.8 \%$ & $17.6 \%$ & $3.6 \%$ & $5.2 \%$ \\
\hline 1995 & 2848.1 & $34.9 \%$ & $13.0 \%$ & $14.8 \%$ & $15.1 \%$ & $7.6 \%$ & $3.9 \%$ \\
\hline 2000 & 5003.9 & $28.2 \%$ & $20.1 \%$ & $13.4 \%$ & $12.8 \%$ & $10.6 \%$ & $5.5 \%$ \\
\hline
\end{tabular}


Table II. Issuers of corporate debt, 1955-2000

\begin{tabular}{|c|c|c|c|c|c|c|}
\hline \multirow[t]{2}{*}{ Year } & \multirow[t]{2}{*}{$\begin{array}{c}\text { Total } \\
\text { liabilities }\end{array}$} & \multirow[t]{2}{*}{$\begin{array}{c}\text { Nonfinancial } \\
\text { corporate } \\
\text { business }\end{array}$} & \multirow[t]{2}{*}{$\begin{array}{l}\text { Foreign } \\
\text { issuers }\end{array}$} & \multirow[t]{2}{*}{$\begin{array}{c}\text { Financial } \\
\text { sectors }\end{array}$} & \multicolumn{2}{|c|}{ Financial sectors } \\
\hline & & & & & $\begin{array}{c}\text { Non-ABS } \\
\text { issuers }\end{array}$ & $\begin{array}{c}\text { ABS } \\
\text { issuers }\end{array}$ \\
\hline 1955 & 60.8 & $89.8 \%$ & $5.1 \%$ & $5.2 \%$ & $5.2 \%$ & $0.0 \%$ \\
\hline 1960 & 91.8 & $83.0 \%$ & $6.3 \%$ & $10.7 \%$ & $10.7 \%$ & $0.0 \%$ \\
\hline 1965 & 123.1 & $79.0 \%$ & $7.4 \%$ & $13.6 \%$ & $13.6 \%$ & $0.0 \%$ \\
\hline 1970 & 204.3 & $81.6 \%$ & $6.9 \%$ & $11.5 \%$ & $11.5 \%$ & $0.0 \%$ \\
\hline 1975 & 336.4 & $75.4 \%$ & $7.9 \%$ & $16.7 \%$ & $16.7 \%$ & $0.0 \%$ \\
\hline 1980 & 507.6 & $72.0 \%$ & $9.7 \%$ & $18.3 \%$ & $18.3 \%$ & $0.0 \%$ \\
\hline 1985 & 883.1 & $65.5 \%$ & $8.1 \%$ & $26.4 \%$ & $22.5 \%$ & $3.9 \%$ \\
\hline 1990 & 1705.7 & $59.1 \%$ & $6.8 \%$ & $34.1 \%$ & $20.1 \%$ & $14.1 \%$ \\
\hline 1995 & 2848.1 & $47.2 \%$ & $10.5 \%$ & $42.3 \%$ & $20.8 \%$ & $21.5 \%$ \\
\hline 2000 & 5003.9 & $44.7 \%$ & $10.0 \%$ & $45.3 \%$ & $21.8 \%$ & $23.6 \%$ \\
\hline
\end{tabular}




\section{Table III. Corporate bond yield spreads}

This table presents corporate bond spreads over the closest benchmark Treasury by credit rating and years to maturity (bps). All bonds are in US Dollars and have no callable features (call, put, sinking fund, convertibility).

Panel A: Breakdown by maturity, 1995-1999

\begin{tabular}{ccccc||ccc}
\multicolumn{5}{c}{} & \multicolumn{5}{c||}{ All sectors } & Industrial & Financial & Utility \\
\cline { 2 - 8 } & AA & A & BBB & Total & Total & Total & Total \\
\hline Short (2-7 years) & 61.27 & 81.03 & 126.60 & 92.33 & 98.99 & 88.80 & 84.56 \\
Medium (7-15 years) & 75.77 & 98.50 & 144.73 & 112.19 & 117.33 & 108.74 & 102.02 \\
Long (15-30 years) & 94.45 & 118.29 & 163.40 & 134.79 & 132.76 & 143.50 & 129.86
\end{tabular}

Panel B: Breakdown by year, All maturities 2-30 years

1995-1999

1995

1996

1997

1998

1999

\begin{tabular}{|c|c|c|c|c|c|c|}
\hline \multicolumn{4}{|c|}{ All sectors } & Industrial & Financial & Utility \\
\hline AA & A & BBB & Total & Total & Total & Total \\
\hline 69.81 & 91.56 & 139.53 & 105.10 & 112.49 & 99.26 & 96.45 \\
\hline 71.43 & 92.15 & 130.99 & 100.92 & 104.89 & 98.13 & 95.92 \\
\hline 55.65 & 67.17 & 97.10 & 74.61 & 78.02 & 71.62 & 73.21 \\
\hline 58.34 & 70.74 & 98.23 & 77.91 & 80.99 & 76.53 & 71.28 \\
\hline 79.65 & 111.34 & 166.55 & 127.33 & 136.78 & 119.34 & 115.80 \\
\hline 85.45 & 111.82 & 174.62 & 133.18 & 140.69 & 125.40 & 125.92 \\
\hline
\end{tabular}




\section{Table IV. Regression results}

All equity data is for the 180 days preceding each bond trade. Twelve month dummies were included in the regressions but are omitted from this table. T-statistics appear in parentheses.

\begin{tabular}{|c|c|c|c|c|c|c|c|c|}
\hline \multicolumn{9}{|l|}{ Equity volatility } \\
\hline $\begin{array}{l}\text { Std. Dev. of daily excess return (\%) } \\
\text { over preceding } 180 \text { days }\end{array}$ & & $\begin{array}{l}221.81 \\
(39.42)\end{array}$ & & $\begin{array}{l}189.16 \\
(34.52)\end{array}$ & & $\begin{array}{l}238.14 \\
(39.93)\end{array}$ & & $\begin{array}{l}199.24 \\
(34.00)\end{array}$ \\
\hline Std. Dev. of daily index return (\%) & & $\begin{array}{l}29.17 \\
(1.52)\end{array}$ & & $\begin{array}{l}46.07 \\
(2.49)\end{array}$ & & $\begin{array}{l}7.24 \\
(0.38)\end{array}$ & & $\begin{array}{l}36.44 \\
(1.96)\end{array}$ \\
\hline Mean daily excess return (\%) & & $\begin{array}{l}-32.07 \\
(-15.13)\end{array}$ & & $\begin{array}{l}-34.22 \\
(-16.74)\end{array}$ & & $\begin{array}{l}-31.50 \\
(-14.85)\end{array}$ & & $\begin{array}{c}-33.31 \\
(-16.22)\end{array}$ \\
\hline Mean daily index return (\%) & & $\begin{array}{l}-105.03 \\
(-14.13)\end{array}$ & & $\begin{array}{l}-102.92 \\
(-14.37)\end{array}$ & & $\begin{array}{l}-108.66 \\
(-14.69)\end{array}$ & & $\begin{array}{l}-104.88 \\
(-14.65)\end{array}$ \\
\hline $\begin{array}{l}\text { Market capitalization relative to } \\
\text { CRSP-value wghtd. index (\%) }\end{array}$ & & $\begin{array}{c}-30.30 \\
(-21.32)\end{array}$ & & $\begin{array}{l}-10.48 \\
(-7.17)\end{array}$ & & $\begin{array}{l}-26.21 \\
(-17.65)\end{array}$ & & $\begin{array}{l}-9.88 \\
(-6.54)\end{array}$ \\
\hline \multicolumn{9}{|l|}{ Credit ratings } \\
\hline A or worse (relative to AA) & & & $\begin{array}{c}17.74 \\
(18.11)\end{array}$ & $\begin{array}{c}13.37 \\
(13.98)\end{array}$ & & & $\begin{array}{c}17.91 \\
(18.17)\end{array}$ & $\begin{array}{c}13.18 \\
(13.65)\end{array}$ \\
\hline $\mathrm{BBB}$ or worse (relative to AA) & & & $\begin{array}{c}32.99 \\
(43.52)\end{array}$ & $\begin{array}{l}26.58 \\
(35.44)\end{array}$ & & & $\begin{array}{c}32.33 \\
(40.75)\end{array}$ & $\begin{array}{c}26.19 \\
(33.59)\end{array}$ \\
\hline \multicolumn{9}{|l|}{ Accounting data } \\
\hline Pretax interest coverage $<5$ & & & & & $\begin{array}{c}8.65 \\
(5.58)\end{array}$ & $\begin{array}{c}0.72 \\
(0.49)\end{array}$ & $\begin{array}{c}3.84 \\
(2.60)\end{array}$ & $\begin{array}{l}-1.36 \\
(-0.96)\end{array}$ \\
\hline $5<=$ Pretax interest coverage $<10$ & & & & & $\begin{array}{l}-2.49 \\
(-1.66)\end{array}$ & $\begin{array}{l}-6.52 \\
(-4.63)\end{array}$ & $\begin{array}{c}3.53 \\
(2.46)\end{array}$ & $\begin{array}{l}-1.60 \\
(-1.17)\end{array}$ \\
\hline $10<=$ Pretax interest coverage $<20$ & & & & & $\begin{array}{l}-2.62 \\
(-1.55)\end{array}$ & $\begin{array}{l}-7.97 \\
(-4.97)\end{array}$ & $\begin{array}{c}5.57 \\
(3.45)\end{array}$ & $\begin{array}{l}-2.21 \\
(-1.42)\end{array}$ \\
\hline Pretax interest coverage $>=20$ & & & & & $\begin{array}{c}0.37 \\
(0.14)\end{array}$ & $\begin{array}{l}-12.86 \\
(-5.09)\end{array}$ & $\begin{array}{c}5.73 \\
(2.24)\end{array}$ & $\begin{array}{l}-7.22 \\
(-2.94)\end{array}$ \\
\hline
\end{tabular}


Table IV (continued). Regression results

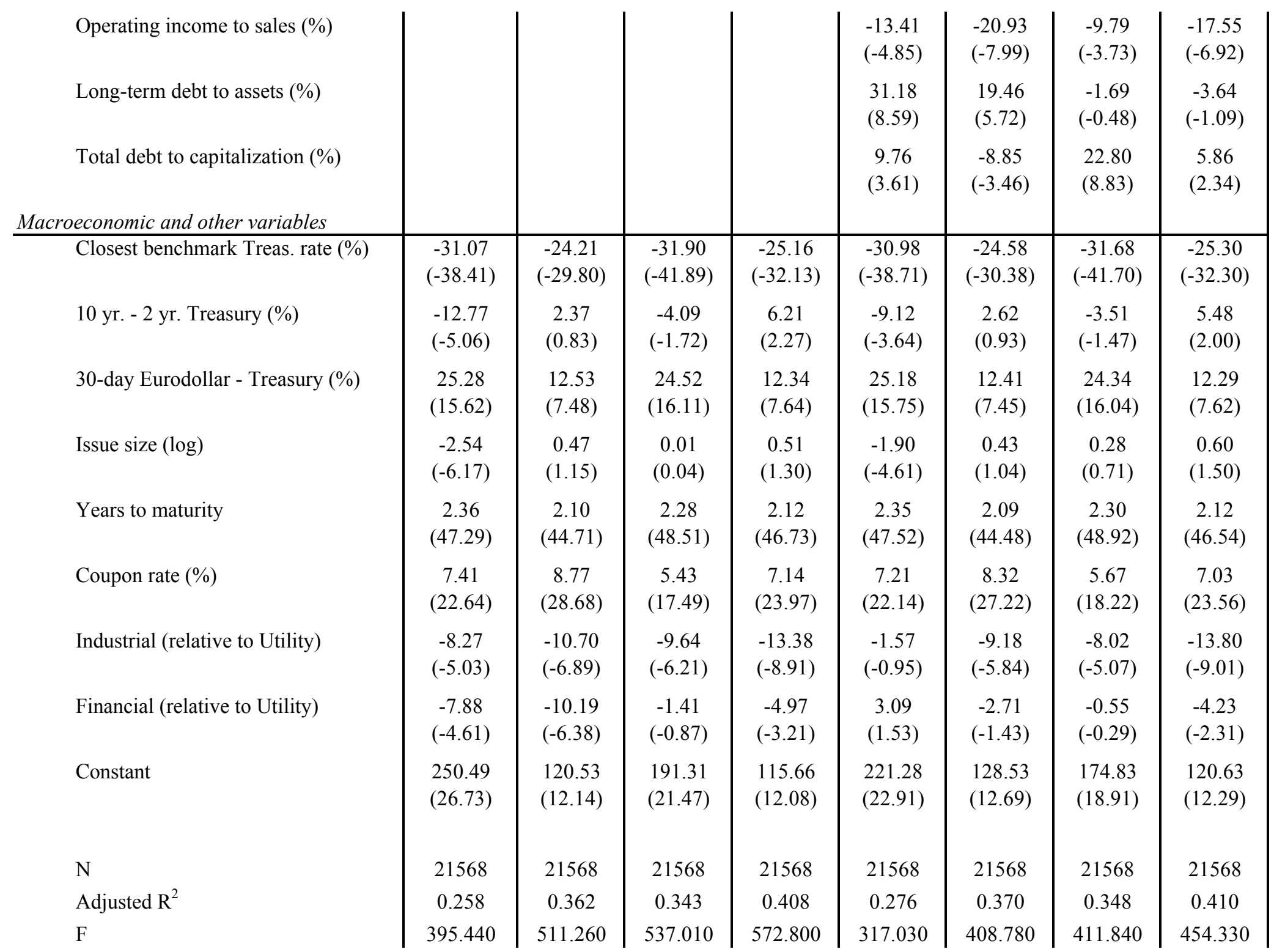




\section{Table V. Regression results with issuer fixed effects}

We include fixed effects for each bond issuer. There is a minimum of one transaction per issuer, a mean of 37.1 transactions, and a maximum of 608 transactions per issuer. All equity data is for the 180 days preceding each bond trade. In Panel A, twelve month dummies were included in the regressions but are omitted from this table. In Panel B, sixty monthly time dummies were included in the regressions but are omitted from this table. T-statistics appear in parentheses.

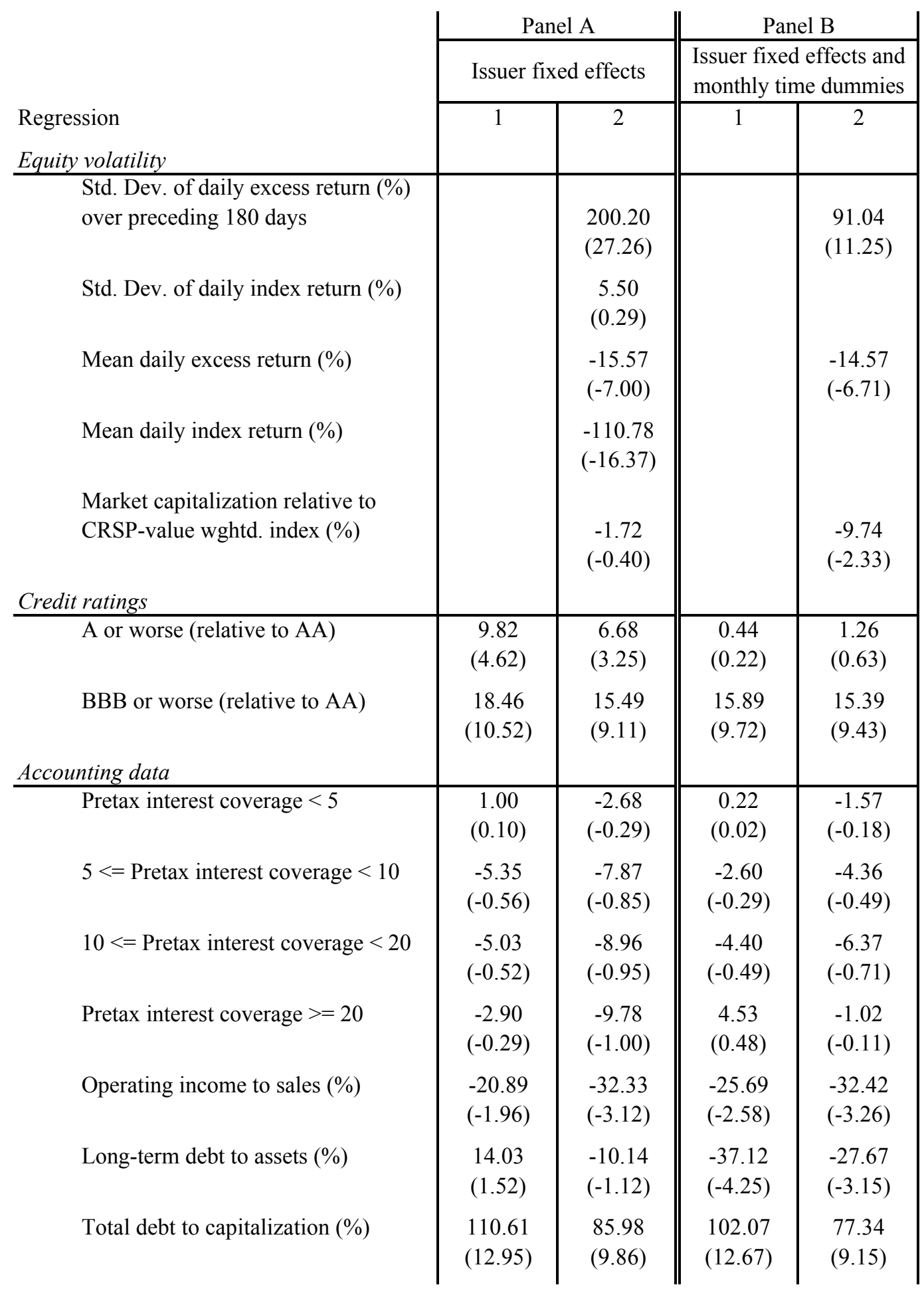


Table V (continued). Regression results with issuer fixed effects

\begin{tabular}{l|c|c||c|c|} 
Macroeconomic and other variables & & & & \\
\hline Closest benchmark Treas. rate (\%) & -32.95 & -26.95 & -24.33 & -25.00 \\
& $(-46.15)$ & $(-35.93)$ & $(-12.84)$ & $(-13.25)$ \\
10 yr. - 2 yr. Treasury (\%) & 1.73 & 5.13 & & \\
30-day Eurodollar - Treasury (\%) & $(0.76)$ & $(1.97)$ & & \\
Issue size (log) & 22.75 & 11.45 & & \\
& $(16.20)$ & $(7.54)$ & & \\
Years to maturity & 2.80 & 2.16 & 1.15 & 1.17 \\
& $(5.42)$ & $(4.31)$ & $(2.38)$ & $(2.43)$ \\
Coupon rate (\%) & 2.36 & 2.26 & 2.20 & 2.22 \\
& $(47.22)$ & $(46.38)$ & $(35.05)$ & $(35.51)$ \\
Constant & 5.21 & 6.03 & 6.23 & 6.22 \\
& $(14.88)$ & $(17.77)$ & $(18.94)$ & $(19.00)$ \\
Number of transactions & 122.01 & 93.89 & 160.73 & 161.82 \\
Number of issuers & $(8.66)$ & $(6.64)$ & $(8.27)$ & $(8.32)$ \\
$\mathrm{R}^{2}$ within & & & & \\
$\mathrm{R}^{2}$ between & 21568 & 21568 & 21568 & 21568 \\
$\mathrm{R}^{2}$ overall & 581 & 581 & 581 & 581 \\
$\mathrm{~F}$ & 0.289 & 0.337 & 0.385 & 0.391 \\
& 0.323 & 0.437 & 0.405 & 0.486 \\
& 0.257 & 0.336 & 0.340 & 0.392 \\
& 327.33 & 342.99 & 184.75 & 181.61
\end{tabular}




\section{Table VI. Interaction effects}

In each regression, there are 21,568 bond transactions among 581 issuers. There is a minimum of one transaction per issuer, a mean of 37.1 transactions, and a maximum of 608 transactions per issuer. The results presented below are for the 180 days preceding each bond transaction using OLS. T-statistics appear in parentheses.

\begin{tabular}{|c|c|c|c|c|}
\hline \multirow{3}{*}{$\begin{array}{l}\text { Interaction variable } \\
\text { Regression } \\
\text { Eguity volatility }\end{array}$} & \multicolumn{2}{|c|}{ Long-term debt to assets } & \multicolumn{2}{|c|}{$\begin{array}{l}\text { Total debt to } \\
\text { capitalization }\end{array}$} \\
\hline & \multirow[t]{2}{*}{1} & \multirow[t]{2}{*}{2} & \multirow[t]{2}{*}{3} & \multirow[t]{2}{*}{4} \\
\hline & & & & \\
\hline $\begin{array}{l}\text { Std. Dev. of daily excess return (\%) } \\
\text { over preceding } 180 \text { days }\end{array}$ & & $\begin{array}{l}91.01 \\
(7.43)\end{array}$ & & $\begin{array}{l}106.81 \\
(8.69)\end{array}$ \\
\hline Std. Dev. of daily index return (\%) & & $\begin{array}{l}54.37 \\
(2.92)\end{array}$ & & $\begin{array}{l}50.79 \\
(2.73)\end{array}$ \\
\hline Mean daily excess return (\%) & & $\begin{array}{l}-32.75 \\
(-15.89)\end{array}$ & & $\begin{array}{l}-31.26 \\
(-15.01)\end{array}$ \\
\hline Mean daily index return (\%) & & $\begin{array}{l}-103.34 \\
(-14.43)\end{array}$ & & $\begin{array}{l}-104.71 \\
(-14.62)\end{array}$ \\
\hline $\begin{array}{l}\text { Market capitalization relative to } \\
\text { CRSP-value wghtd. index (\%) }\end{array}$ & & $\begin{array}{l}-12.29 \\
(-8.21)\end{array}$ & & $\begin{array}{l}-12.81 \\
(-8.61)\end{array}$ \\
\hline \multicolumn{5}{|l|}{ Interaction effects } \\
\hline $\begin{array}{l}\text { Std. Dev. excess return * }(1 / 10<= \\
\text { Interaction variable }<1 / 4)\end{array}$ & & $\begin{array}{l}105.37 \\
(7.56)\end{array}$ & & $\begin{array}{l}62.30 \\
(4.33)\end{array}$ \\
\hline $\begin{array}{l}\text { Std. Dev. excess return } *(1 / 4<= \\
\text { Interaction variable }<1 / 3)\end{array}$ & & $\begin{array}{l}103.75 \\
(6.61)\end{array}$ & & $\begin{array}{l}108.85 \\
(6.60)\end{array}$ \\
\hline $\begin{array}{l}\text { Std. Dev. excess return * (Interaction } \\
\text { variable }>=1 / 3)\end{array}$ & & $\begin{array}{l}135.33 \\
(8.72)\end{array}$ & & $\begin{array}{l}109.35 \\
(7.63)\end{array}$ \\
\hline $\begin{array}{l}\text { Treasury rate } *(1 / 10<=\text { Long-term } \\
\text { debt to total assets }<1 / 4)\end{array}$ & $\begin{array}{l}-5.74 \\
(-3.91)\end{array}$ & $\begin{array}{l}-1.30 \\
(-0.88)\end{array}$ & & \\
\hline $\begin{array}{l}\text { Treasury rate } *(1 / 4<=\text { Long-term } \\
\text { debt to total assets }<1 / 3)\end{array}$ & $\begin{array}{l}-2.96 \\
(-1.84)\end{array}$ & $\begin{array}{c}1.26 \\
(0.77)\end{array}$ & & \\
\hline $\begin{array}{l}\text { Treasury rate } * \text { (Long-term debt to } \\
\text { total assets }>=1 / 3)\end{array}$ & $\begin{array}{l}-7.00 \\
(-4.03)\end{array}$ & $\begin{array}{l}-2.99 \\
(-1.73)\end{array}$ & & \\
\hline \multicolumn{5}{|l|}{ Credit ratings } \\
\hline A or worse (relative to AA) & $\begin{array}{c}17.96 \\
(18.18)\end{array}$ & $\begin{array}{c}13.11 \\
(13.51)\end{array}$ & $\begin{array}{c}17.63 \\
(17.92)\end{array}$ & $\begin{array}{c}13.26 \\
(13.71)\end{array}$ \\
\hline $\mathrm{BBB}$ or worse (relative to $\mathrm{AA}$ ) & $\begin{array}{c}31.77 \\
(40.29)\end{array}$ & $\begin{array}{c}25.65 \\
(33.05)\end{array}$ & $\begin{array}{c}32.31 \\
(40.94)\end{array}$ & $\begin{array}{c}26.05 \\
(33.53)\end{array}$ \\
\hline
\end{tabular}


Table VI (continued). Interaction effects

Accounting data

\begin{tabular}{|c|c|c|c|c|}
\hline $1 / 10<=$ Interaction variable $<1 / 4$ & $\begin{array}{l}35.73 \\
(4.19)\end{array}$ & $\begin{array}{l}-11.79 \\
(-1.21)\end{array}$ & $\begin{array}{c}0.26 \\
(0.23)\end{array}$ & $\begin{array}{l}-11.86 \\
(-4.28)\end{array}$ \\
\hline $1 / 4<=$ Interaction variable $<1 / 3$ & $\begin{array}{l}12.41 \\
(1.33)\end{array}$ & $\begin{array}{l}-31.60 \\
(-2.93)\end{array}$ & $\begin{array}{c}1.99 \\
(1.36)\end{array}$ & $\begin{array}{l}-21.89 \\
(-6.65)\end{array}$ \\
\hline Interaction variable $>=1 / 3$ & $\begin{array}{l}39.20 \\
(3.88)\end{array}$ & $\begin{array}{l}-11.70 \\
(-1.04)\end{array}$ & $\begin{array}{c}17.18 \\
(11.84)\end{array}$ & $\begin{array}{l}-11.95 \\
(-3.96)\end{array}$ \\
\hline Pretax interest coverage $<5$ & $\begin{array}{c}0.36 \\
(0.28)\end{array}$ & $\begin{array}{c}-2.50 \\
(-1.96)\end{array}$ & $\begin{array}{c}0.67 \\
(0.55)\end{array}$ & $\begin{array}{c}-6.02 \\
(-5.06)\end{array}$ \\
\hline $5<=$ Pretax interest coverage $<10$ & $\begin{array}{c}-1.59 \\
(-1.28)\end{array}$ & $\begin{array}{c}-4.20 \\
(-3.42)\end{array}$ & $\begin{array}{c}1.03 \\
(0.85)\end{array}$ & $\begin{array}{c}-6.60 \\
(-5.61)\end{array}$ \\
\hline $10<=$ Pretax interest coverage $<20$ & $\begin{array}{c}-0.42 \\
(-0.29)\end{array}$ & $\begin{array}{c}-5.05 \\
(-3.54)\end{array}$ & $\begin{array}{c}1.22 \\
(0.81)\end{array}$ & $\begin{array}{c}-7.06 \\
(-4.73)\end{array}$ \\
\hline Pretax interest coverage $>=20$ & $\begin{array}{c}0.93 \\
(0.39)\end{array}$ & $\begin{array}{c}-8.65 \\
(-3.65)\end{array}$ & $\begin{array}{c}0.07 \\
(0.03)\end{array}$ & $\begin{array}{l}-11.66 \\
(-4.72)\end{array}$ \\
\hline Operating income to sales $(\%)$ & $\begin{array}{c}-6.95 \\
(-2.75)\end{array}$ & $\begin{array}{l}-13.35 \\
(-5.42)\end{array}$ & $\begin{array}{c}-2.63 \\
(-1.21)\end{array}$ & $\begin{array}{l}-14.61 \\
(-6.84)\end{array}$ \\
\hline Long-term debt to assets $(\%)$ & & & $\begin{array}{l}-10.95 \\
(-3.34)\end{array}$ & $\begin{array}{l}-10.95 \\
(-3.49)\end{array}$ \\
\hline $\begin{array}{l}\text { Total debt to capitalization }(\%) \\
\text { Macroeconomic and other variables }\end{array}$ & $\begin{array}{c}27.40 \\
(11.05)\end{array}$ & $\begin{array}{l}12.36 \\
(5.09)\end{array}$ & & \\
\hline Closest benchmark Treas. rate $(\%)$ & $\begin{array}{c}-27.71 \\
(-21.67)\end{array}$ & $\begin{array}{c}-24.76 \\
(-19.20)\end{array}$ & $\begin{array}{c}-31.58 \\
(-41.65)\end{array}$ & $\begin{array}{c}-25.21 \\
(-32.16)\end{array}$ \\
\hline 10 yr. - 2 yr. Treasury (\%) & $\begin{array}{c}-3.15 \\
(-1.32)\end{array}$ & $\begin{array}{c}6.13 \\
(2.23)\end{array}$ & $\begin{array}{c}-3.47 \\
(-1.46)\end{array}$ & $\begin{array}{c}5.73 \\
(2.11)\end{array}$ \\
\hline 30-day Eurodollar - Treasury (\%) & $\begin{array}{c}24.42 \\
(16.09)\end{array}$ & $\begin{array}{l}12.85 \\
(7.96)\end{array}$ & $\begin{array}{c}24.33 \\
(16.07)\end{array}$ & $\begin{array}{l}12.55 \\
(7.78)\end{array}$ \\
\hline Issue size $(\log )$ & $\begin{array}{c}-0.19 \\
(-0.50)\end{array}$ & $\begin{array}{c}0.08 \\
(0.21)\end{array}$ & $\begin{array}{c}-0.22 \\
(-0.58)\end{array}$ & $\begin{array}{c}0.27 \\
(0.67)\end{array}$ \\
\hline Years to maturity & $\begin{array}{c}2.29 \\
(48.86)\end{array}$ & $\begin{array}{c}2.09 \\
(45.86)\end{array}$ & $\begin{array}{c}2.28 \\
(48.77)\end{array}$ & $\begin{array}{c}2.09 \\
(46.20)\end{array}$ \\
\hline Coupon rate $(\%)$ & $\begin{array}{c}5.55 \\
(17.82)\end{array}$ & $\begin{array}{c}6.84 \\
(22.93)\end{array}$ & $\begin{array}{c}5.66 \\
(18.26)\end{array}$ & $\begin{array}{c}6.88 \\
(23.08)\end{array}$ \\
\hline Constant & $\begin{array}{l}158.16 \\
(14.65)\end{array}$ & $\begin{array}{l}136.18 \\
(11.60)\end{array}$ & $\begin{array}{l}183.31 \\
(20.52)\end{array}$ & $\begin{array}{c}137.93 \\
(14.03)\end{array}$ \\
\hline Number of transactions & 21568 & 21568 & 21568 & 21568 \\
\hline Adjusted $\mathrm{R}^{2}$ & 0.348 & 0.410 & 0.351 & 0.410 \\
\hline $\mathrm{F}$ & 372.96 & 384.58 & 418.03 & 417.95 \\
\hline
\end{tabular}




\section{Table VII. Robustness checks}

All equity data is for the number of days specified below preceding each bond trade. Month dummies were included in the regressions (using OLS) but are omitted from this table. T-statistics appear in parentheses.

\begin{tabular}{|c|c|c|c|c|}
\hline No. of days of preceding each bond trade & 90 & 180 & 270 & 360 \\
\hline $\begin{array}{l}\text { Regression } \\
\text { Equity volatility }\end{array}$ & 1 & 2 & 3 & 4 \\
\hline Beta $*$ Std. Dev. of daily index return & $\begin{array}{l}-47.96 \\
(-6.97)\end{array}$ & $\begin{array}{l}-72.67 \\
(-9.09)\end{array}$ & $\begin{array}{l}-98.61 \\
(-10.95)\end{array}$ & $\begin{array}{l}-81.84 \\
(-8.33)\end{array}$ \\
\hline Idiosyncratic risk & $\begin{array}{l}171.07 \\
(32.58)\end{array}$ & $\begin{array}{l}227.71 \\
(38.54)\end{array}$ & $\begin{array}{l}260.86 \\
(40.45)\end{array}$ & $\begin{array}{l}276.75 \\
(39.13)\end{array}$ \\
\hline $\begin{array}{l}\text { Market capitalization relative to } \\
\text { CRSP-value wghtd. index (\%) }\end{array}$ & $\begin{array}{l}-12.31 \\
(-7.89)\end{array}$ & $\begin{array}{l}-10.38 \\
(-6.66)\end{array}$ & $\begin{array}{l}-8.43 \\
(-5.38)\end{array}$ & $\begin{array}{l}-9.14 \\
(-5.81)\end{array}$ \\
\hline Credit ratings & & & & \\
\hline A or worse (relative to AA) & $\begin{array}{c}13.38 \\
(13.56)\end{array}$ & $\begin{array}{c}12.70 \\
(12.98)\end{array}$ & $\begin{array}{c}12.32 \\
(12.64)\end{array}$ & $\begin{array}{l}12.03 \\
(12.34)\end{array}$ \\
\hline $\mathrm{BBB}$ or worse (relative to $\mathrm{AA}$ ) & $\begin{array}{l}26.90 \\
(33.81)\end{array}$ & $\begin{array}{c}26.02 \\
(32.99)\end{array}$ & $\begin{array}{c}25.42 \\
(32.29)\end{array}$ & $\begin{array}{c}25.11 \\
(31.87)\end{array}$ \\
\hline Accounting data & & & & \\
\hline Pretax interest coverage $<5$ & $\begin{array}{c}0.09 \\
(0.07)\end{array}$ & $\begin{array}{l}-1.16 \\
(-0.82)\end{array}$ & $\begin{array}{c}-1.64 \\
(-1.15)\end{array}$ & $\begin{array}{c}-2.11 \\
(-1.48)\end{array}$ \\
\hline $5<=$ Pretax interest coverage $<10$ & $\begin{array}{c}0.58 \\
(0.41)\end{array}$ & $\begin{array}{l}-0.42 \\
(-0.30)\end{array}$ & $\begin{array}{c}-0.90 \\
(-0.65)\end{array}$ & $\begin{array}{l}-1.51 \\
(-1.09)\end{array}$ \\
\hline $10<=$ Pretax interest coverage $<20$ & $\begin{array}{c}0.54 \\
(0.34)\end{array}$ & $\begin{array}{l}-1.68 \\
(-1.06)\end{array}$ & $\begin{array}{l}-3.10 \\
(-1.97)\end{array}$ & $\begin{array}{c}-4.02 \\
(-2.55)\end{array}$ \\
\hline Pretax interest coverage $>=20$ & $\begin{array}{l}-2.79 \\
(-1.12)\end{array}$ & $\begin{array}{l}-5.70 \\
(-2.30)\end{array}$ & $\begin{array}{l}-7.05 \\
(-2.85)\end{array}$ & $\begin{array}{l}-8.43 \\
(-3.41)\end{array}$ \\
\hline Operating income to sales (\%) & $\begin{array}{l}-14.16 \\
(-5.44)\end{array}$ & $\begin{array}{l}-15.43 \\
(-5.97)\end{array}$ & $\begin{array}{l}-15.79 \\
(-6.13)\end{array}$ & $\begin{array}{l}-18.26 \\
(-7.09)\end{array}$ \\
\hline Long-term debt to assets $(\%)$ & $\begin{array}{l}-4.83 \\
(-1.39)\end{array}$ & $\begin{array}{l}-7.62 \\
(-2.20)\end{array}$ & $\begin{array}{l}-9.10 \\
(-2.63)\end{array}$ & $\begin{array}{l}-7.40 \\
(-2.14)\end{array}$ \\
\hline Total debt to capitalization (\%) & $\begin{array}{l}12.67 \\
(4.96)\end{array}$ & $\begin{array}{c}9.86 \\
(3.89)\end{array}$ & $\begin{array}{c}8.78 \\
(3.47)\end{array}$ & $\begin{array}{c}6.95 \\
(2.75)\end{array}$ \\
\hline Macroeconomic and other variables & & & & \\
\hline Closest benchmark Treas. rate $(\%)$ & $\begin{array}{c}-28.36 \\
(-37.34)\end{array}$ & $\begin{array}{c}-28.71 \\
(-38.05)\end{array}$ & $\begin{array}{c}-30.51 \\
(-40.40)\end{array}$ & $\begin{array}{l}-31.39 \\
(-41.94)\end{array}$ \\
\hline 10 yr. - 2 yr. Treasury (\%) & $\begin{array}{c}1.41 \\
(0.61)\end{array}$ & $\begin{array}{c}6.52 \\
(2.78)\end{array}$ & $\begin{array}{c}7.26 \\
(3.07)\end{array}$ & $\begin{array}{c}9.87 \\
(4.18)\end{array}$ \\
\hline 30-day Eurodollar - Treasury (\%) & $\begin{array}{c}21.50 \\
(14.38)\end{array}$ & $\begin{array}{c}23.85 \\
(16.31)\end{array}$ & $\begin{array}{c}23.67 \\
(16.17)\end{array}$ & $\begin{array}{c}23.43 \\
(16.08)\end{array}$ \\
\hline Issue size $(\log )$ & $\begin{array}{c}0.92 \\
(2.27)\end{array}$ & $\begin{array}{c}0.84 \\
(2.09)\end{array}$ & $\begin{array}{c}0.57 \\
(1.43)\end{array}$ & $\begin{array}{c}0.40 \\
(1.00)\end{array}$ \\
\hline
\end{tabular}


Table VII (continued). Robustness checks

\begin{tabular}{|c|c|c|c|c|}
\hline Years to maturity & $\begin{array}{c}2.18 \\
(47.30)\end{array}$ & $\begin{array}{c}2.20 \\
(48.21)\end{array}$ & $\begin{array}{c}2.26 \\
(49.46)\end{array}$ & $\begin{array}{c}2.28 \\
(50.17)\end{array}$ \\
\hline Coupon rate $(\%)$ & $\begin{array}{c}6.54 \\
(21.52)\end{array}$ & $\begin{array}{c}6.79 \\
(22.54)\end{array}$ & $\begin{array}{c}6.98 \\
(23.25)\end{array}$ & $\begin{array}{c}7.08 \\
(23.56)\end{array}$ \\
\hline Industrial (relative to Utility) & $\begin{array}{l}-12.97 \\
(-8.26)\end{array}$ & $\begin{array}{l}-14.81 \\
(-9.50)\end{array}$ & $\begin{array}{l}-15.33 \\
(-9.86)\end{array}$ & $\begin{array}{c}-16.19 \\
(-10.42)\end{array}$ \\
\hline Financial (relative to Utility) & $\begin{array}{c}-3.35 \\
(-1.77)\end{array}$ & $\begin{array}{c}-4.25 \\
(-2.27)\end{array}$ & $\begin{array}{c}-3.79 \\
(-2.03)\end{array}$ & $\begin{array}{c}-4.79 \\
(-2.56)\end{array}$ \\
\hline Constant & $\begin{array}{l}132.56 \\
(14.29)\end{array}$ & $\begin{array}{l}128.46 \\
(13.93)\end{array}$ & $\begin{array}{l}140.47 \\
(15.29)\end{array}$ & $\begin{array}{l}145.56 \\
(15.91)\end{array}$ \\
\hline Number of transactions & 21568 & 21568 & 21568 & 21568 \\
\hline Adjusted $\mathrm{R}^{2}$ & 0.382 & 0.394 & 0.399 & 0.399 \\
\hline $\mathrm{F}$ & 431.65 & 453.68 & 462.62 & 463.60 \\
\hline
\end{tabular}




\section{Table VIII. Regressions with Nelson-Siegel yield errors}

Panel A: We model the price of each bond following Nelson and Siegel (1987) and compute the corresponding yield spread. Regressions use the actual yield spread minus the estimated yield spread. Panel B: We regress actual bond spreads against the variables in Panel A and sixty monthly time dummies. All equity data is for the 180 days preceding each bond trade. T-statistics appear in parentheses.

\begin{tabular}{|c|c|c|c|c|c|c|}
\hline & & & Indi & ials & & \\
\hline & & Panel A & & & Panel B & \\
\hline & AA & A & BBB & AA & $\mathrm{A}$ & BBB \\
\hline Regression & 1 & 2 & 3 & 1 & 2 & 3 \\
\hline Equity volatility & & & & & & \\
\hline Std. Dev. of daily excess return (\%) & $\begin{array}{l}23.26 \\
(1.09)\end{array}$ & $\begin{array}{l}67.83 \\
(8.34)\end{array}$ & $\begin{array}{l}73.74 \\
(9.92)\end{array}$ & $\begin{array}{l}60.83 \\
(2.26)\end{array}$ & $\begin{array}{l}68.32 \\
(7.08)\end{array}$ & $\begin{array}{c}96.75 \\
(11.13)\end{array}$ \\
\hline Std. Dev. of daily index return (\%) & $\begin{array}{l}-32.84 \\
(-1.18)\end{array}$ & $\begin{array}{l}-63.23 \\
(-4.11)\end{array}$ & $\begin{array}{r}-110.10 \\
(-5.60)\end{array}$ & $\begin{array}{l}-219.52 \\
(-0.84)\end{array}$ & $\begin{array}{l}-618.21 \\
(-4.42)\end{array}$ & $\begin{array}{l}-467.79 \\
(-2.71)\end{array}$ \\
\hline Mean daily excess return (\%) & $\begin{array}{c}3.75 \\
(0.69)\end{array}$ & $\begin{array}{l}-11.46 \\
(-4.46)\end{array}$ & $\begin{array}{l}-26.95 \\
(-9.50)\end{array}$ & $\begin{array}{c}0.04 \\
(0.01)\end{array}$ & $\begin{array}{l}-11.51 \\
(-4.03)\end{array}$ & $\begin{array}{l}-31.68 \\
(-10.13)\end{array}$ \\
\hline Mean daily index return (\%) & $\begin{array}{c}3.89 \\
(0.30)\end{array}$ & $\begin{array}{l}-6.82 \\
(-1.01)\end{array}$ & $\begin{array}{l}-13.62 \\
(-1.54)\end{array}$ & $\begin{array}{l}-40.01 \\
(-0.91)\end{array}$ & $\begin{array}{l}-34.08 \\
(-1.64)\end{array}$ & $\begin{array}{l}-52.07 \\
(-1.88)\end{array}$ \\
\hline Credit ratings & & & & & & \\
\hline Plus rating * Years to maturity & $\begin{array}{c}0.48 \\
(1.11)\end{array}$ & $\begin{array}{c}-1.81 \\
(-10.30)\end{array}$ & $\begin{array}{l}-1.26 \\
(-6.16)\end{array}$ & $\begin{array}{l}1.15 \\
(2.44)\end{array}$ & $\begin{array}{l}-1.44 \\
(-7.58)\end{array}$ & $\begin{array}{c}-0.71 \\
(-3.28)\end{array}$ \\
\hline Minus rating * Years to maturity & $\begin{array}{c}0.50 \\
(2.26)\end{array}$ & $\begin{array}{c}0.79 \\
(5.28)\end{array}$ & $\begin{array}{c}1.48 \\
(7.20)\end{array}$ & $\begin{array}{c}0.85 \\
(3.49)\end{array}$ & $\begin{array}{c}1.12 \\
(6.92)\end{array}$ & $\begin{array}{c}2.18 \\
(10.00)\end{array}$ \\
\hline S\&P stronger than Moody's & $\begin{array}{l}-2.29 \\
(-1.44)\end{array}$ & $\begin{array}{l}-1.24 \\
(-1.21)\end{array}$ & $\begin{array}{c}1.32 \\
(1.01)\end{array}$ & $\begin{array}{c}-0.27 \\
(-0.16)\end{array}$ & $\begin{array}{c}-0.04 \\
(-0.04)\end{array}$ & $\begin{array}{c}3.13 \\
(2.25)\end{array}$ \\
\hline Moody's stronger than S\&P & $\begin{array}{c}5.33 \\
(1.08)\end{array}$ & $\begin{array}{l}-3.89 \\
(-3.18)\end{array}$ & $\begin{array}{c}-0.58 \\
(-0.36)\end{array}$ & $\begin{array}{c}5.90 \\
(1.08)\end{array}$ & $\begin{array}{l}-3.56 \\
(-2.71)\end{array}$ & $\begin{array}{c}0.88 \\
(0.51)\end{array}$ \\
\hline Other variables & & & & & & \\
\hline Coupon rate $(\%)$ & $\begin{array}{c}3.07 \\
(4.65)\end{array}$ & $\begin{array}{c}3.81 \\
(10.49)\end{array}$ & $\begin{array}{c}3.31 \\
(5.94)\end{array}$ & $\begin{array}{c}1.69 \\
(2.34)\end{array}$ & $\begin{array}{c}1.86 \\
(4.71)\end{array}$ & $\begin{array}{c}1.53 \\
(2.57)\end{array}$ \\
\hline Age less than one year & $\begin{array}{l}-3.60 \\
(-1.82)\end{array}$ & $\begin{array}{l}-1.29 \\
(-1.35)\end{array}$ & $\begin{array}{c}2.11 \\
(1.77)\end{array}$ & $\begin{array}{l}-1.19 \\
(-0.54)\end{array}$ & $\begin{array}{c}0.89 \\
(0.87)\end{array}$ & $\begin{array}{c}6.02 \\
(4.75)\end{array}$ \\
\hline Constant & $\begin{array}{l}-27.67 \\
(-4.42)\end{array}$ & $\begin{array}{l}-34.54 \\
(-9.83)\end{array}$ & $\begin{array}{l}-36.29 \\
(-6.96)\end{array}$ & $\begin{array}{l}55.09 \\
(2.67)\end{array}$ & $\begin{array}{l}103.43 \\
(7.34)\end{array}$ & $\begin{array}{l}100.78 \\
(7.44)\end{array}$ \\
\hline $\mathrm{N}$ & 784 & 3338 & 2844 & 784 & 3338 & 2844 \\
\hline Adjusted $\mathrm{R}^{2}$ & 0.043 & 0.121 & 0.117 & 0.454 & 0.541 & 0.630 \\
\hline F & 4.53 & 47.05 & 38.63 & 10.57 & 58.80 & 72.07 \\
\hline
\end{tabular}




\section{Table IX. Standard and Poor's and Moody's spreads}

We regress the Standard and Poor's and Moody's A-rated corporate bond index on a six-month moving average of market and idiosyncratic risk between January 1963 and December 1999. T-statistics appear in parentheses.

\begin{tabular}{|c|c|c|c|c|c|c|}
\hline \multirow[b]{2}{*}{$\begin{array}{l}\text { Regression } \\
\text { Equity volatility }\end{array}$} & \multicolumn{3}{|c|}{$\begin{array}{c}\text { Panel A } \\
\text { Standard and Poor's (S\&P) }\end{array}$} & \multicolumn{3}{|c|}{$\begin{array}{l}\text { Panel B } \\
\text { Moody's }\end{array}$} \\
\hline & 1 & 2 & 3 & 1 & 2 & 3 \\
\hline Market risk & & $\begin{array}{l}14.86 \\
(0.48)\end{array}$ & $\begin{array}{l}51.04 \\
(1.78)\end{array}$ & & $\begin{array}{l}174.10 \\
(3.77)\end{array}$ & $\begin{array}{l}179.94 \\
(3.89)\end{array}$ \\
\hline Idiosyncratic risk & & $\begin{array}{c}9.15 \\
(19.19)\end{array}$ & $\begin{array}{c}5.56 \\
(9.13)\end{array}$ & & $\begin{array}{c}2.58 \\
(3.66)\end{array}$ & $\begin{array}{c}1.32 \\
(1.34)\end{array}$ \\
\hline Macroeconomic and other variables & & & & & & \\
\hline 10-year Treasury rate $(\%)$ & $\begin{array}{c}0.36 \\
(0.42)\end{array}$ & $\begin{array}{l}-2.42 \\
(-3.75)\end{array}$ & $\begin{array}{l}-8.44 \\
(-9.30)\end{array}$ & $\begin{array}{c}5.51 \\
(5.73)\end{array}$ & $\begin{array}{c}4.42 \\
(4.63)\end{array}$ & $\begin{array}{c}5.41 \\
(3.70)\end{array}$ \\
\hline 10-year minus 2-year Treasury (\%) & $\begin{array}{c}49.98 \\
(16.20)\end{array}$ & $\begin{array}{c}29.37 \\
(11.68)\end{array}$ & $\begin{array}{l}22.87 \\
(9.56)\end{array}$ & $\begin{array}{l}11.41 \\
(3.29)\end{array}$ & $\begin{array}{c}6.06 \\
(1.63)\end{array}$ & $\begin{array}{c}4.83 \\
(1.26)\end{array}$ \\
\hline $\begin{array}{l}\text { Aggregate ratio of corporate bonds to } \\
\text { assets (\%) }\end{array}$ & & & $\begin{array}{c}3.01 \\
(6.65)\end{array}$ & & & $\begin{array}{l}-1.37 \\
(-1.87)\end{array}$ \\
\hline Debt turnover $(\%)$ & & & $\begin{array}{c}5.88 \\
(5.35)\end{array}$ & & & $\begin{array}{l}4.88 \\
(2.76)\end{array}$ \\
\hline Constant & $\begin{array}{c}0.81 \\
(11.82)\end{array}$ & $\begin{array}{l}-0.40 \\
(-5.00)\end{array}$ & $\begin{array}{c}-0.30 \\
(-3.20)\end{array}$ & $\begin{array}{c}0.60 \\
(7.83)\end{array}$ & $\begin{array}{c}0.21 \\
(1.82)\end{array}$ & $\begin{array}{c}0.51 \\
(3.36)\end{array}$ \\
\hline Number of observations & 444 & 444 & 444 & 444 & 444 & 444 \\
\hline Adjusted $\mathrm{R}^{2}$ & 0.370 & 0.661 & 0.719 & 0.086 & 0.145 & 0.159 \\
\hline $\mathrm{F}$ & 131.23 & 216.78 & 189.88 & 21.74 & 19.74 & 14.92 \\
\hline
\end{tabular}


Figure 1. Monthly Index Comparisons, 1990-2000

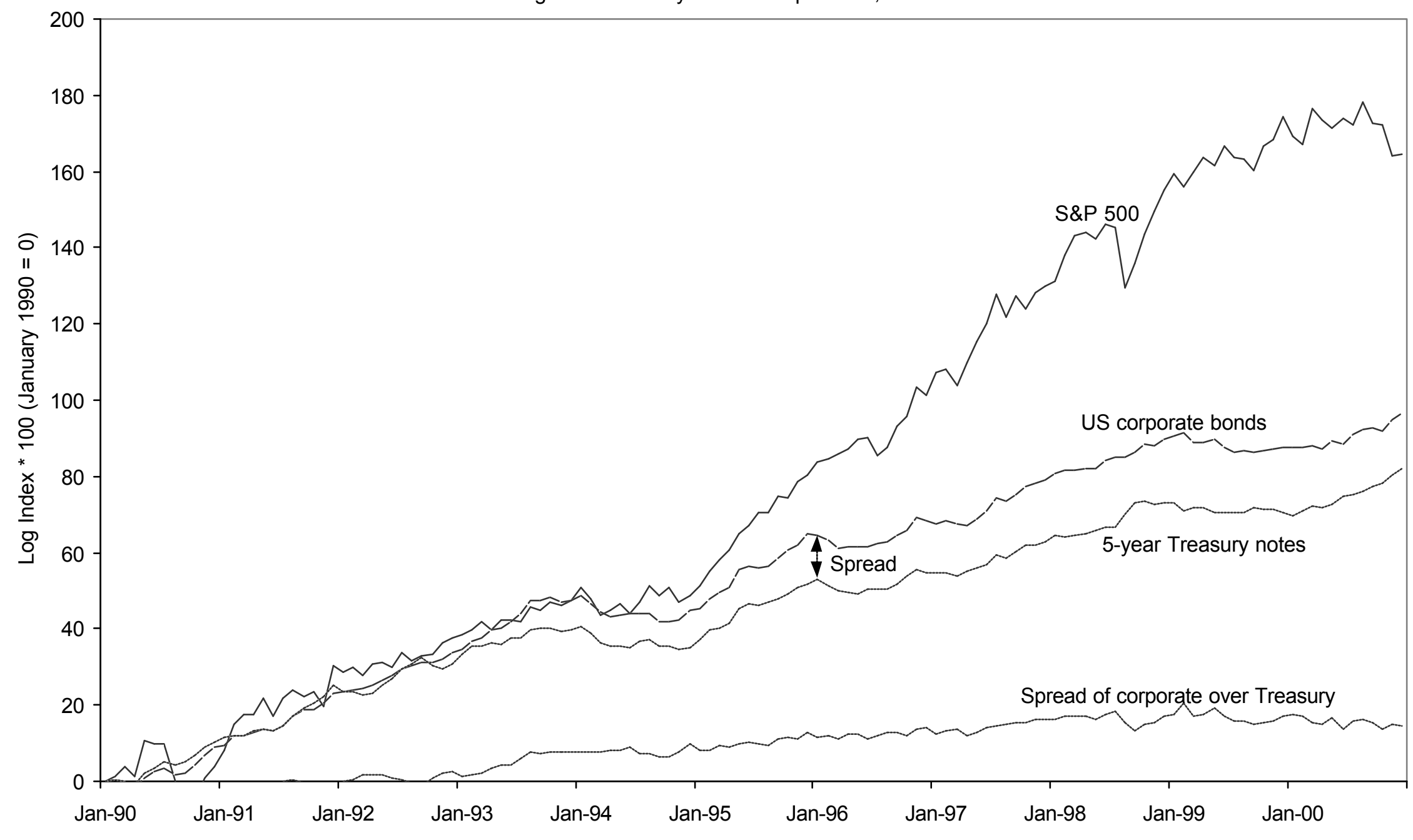

(Source: Global Financial Data) 


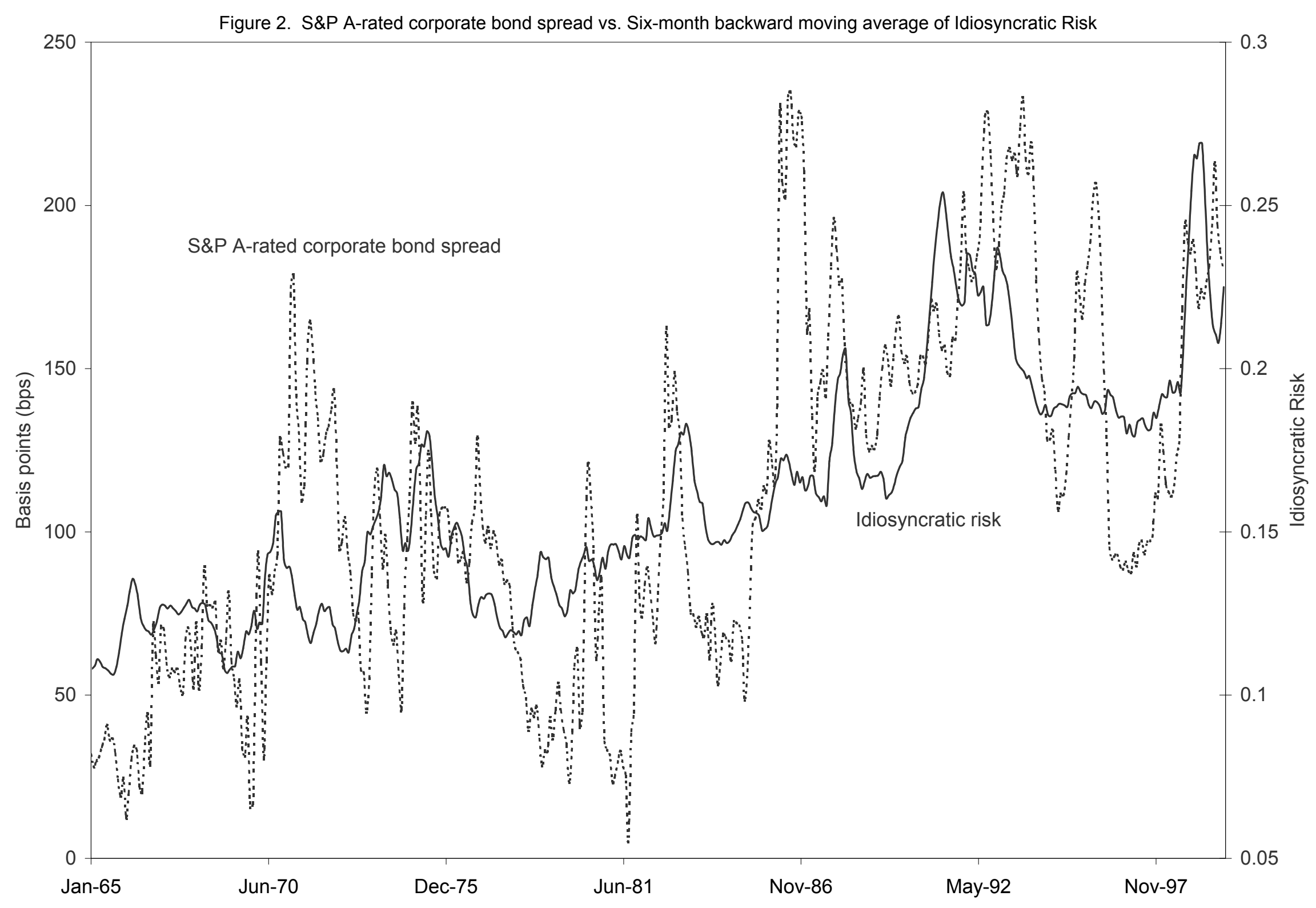


Figure 3. S\&P corporate bond spreads, 1965 to 2000 (bps)

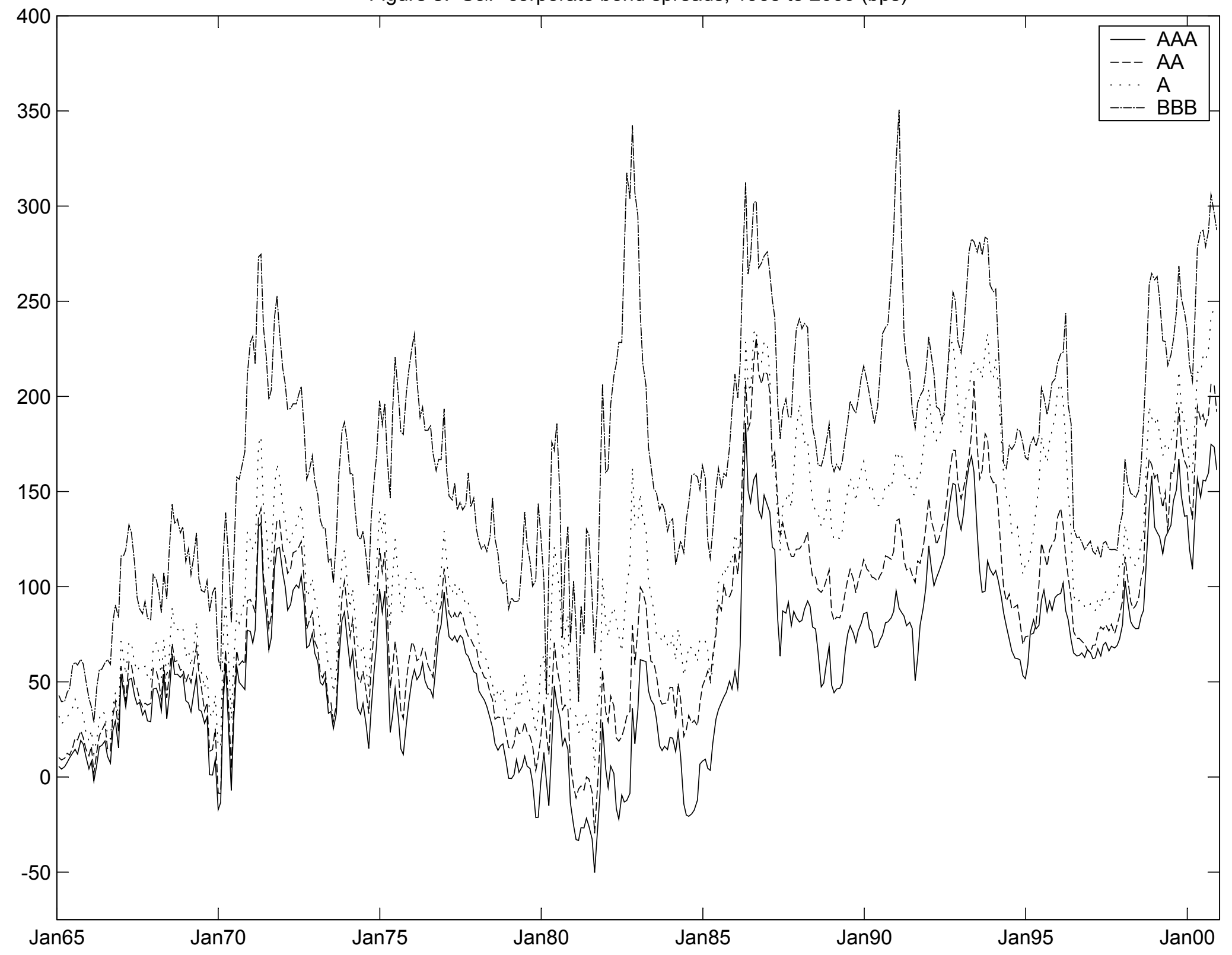


Figure 4. Moodys corporate bond spreads, 1965 to 2000 (bps)

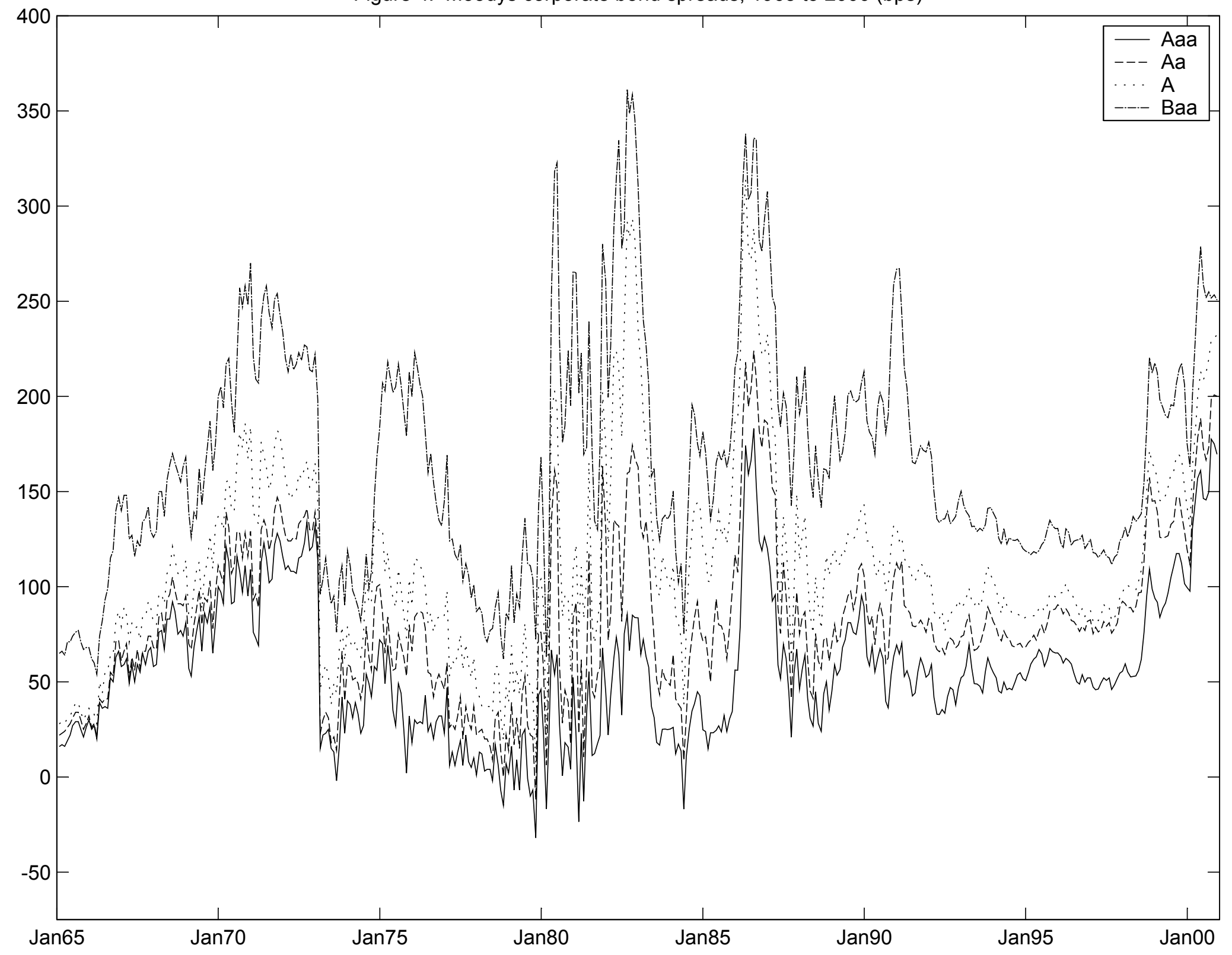


Figure 5. A-rated corporate bond yield spreads over US Treasurys, 1995-1999 (bps)

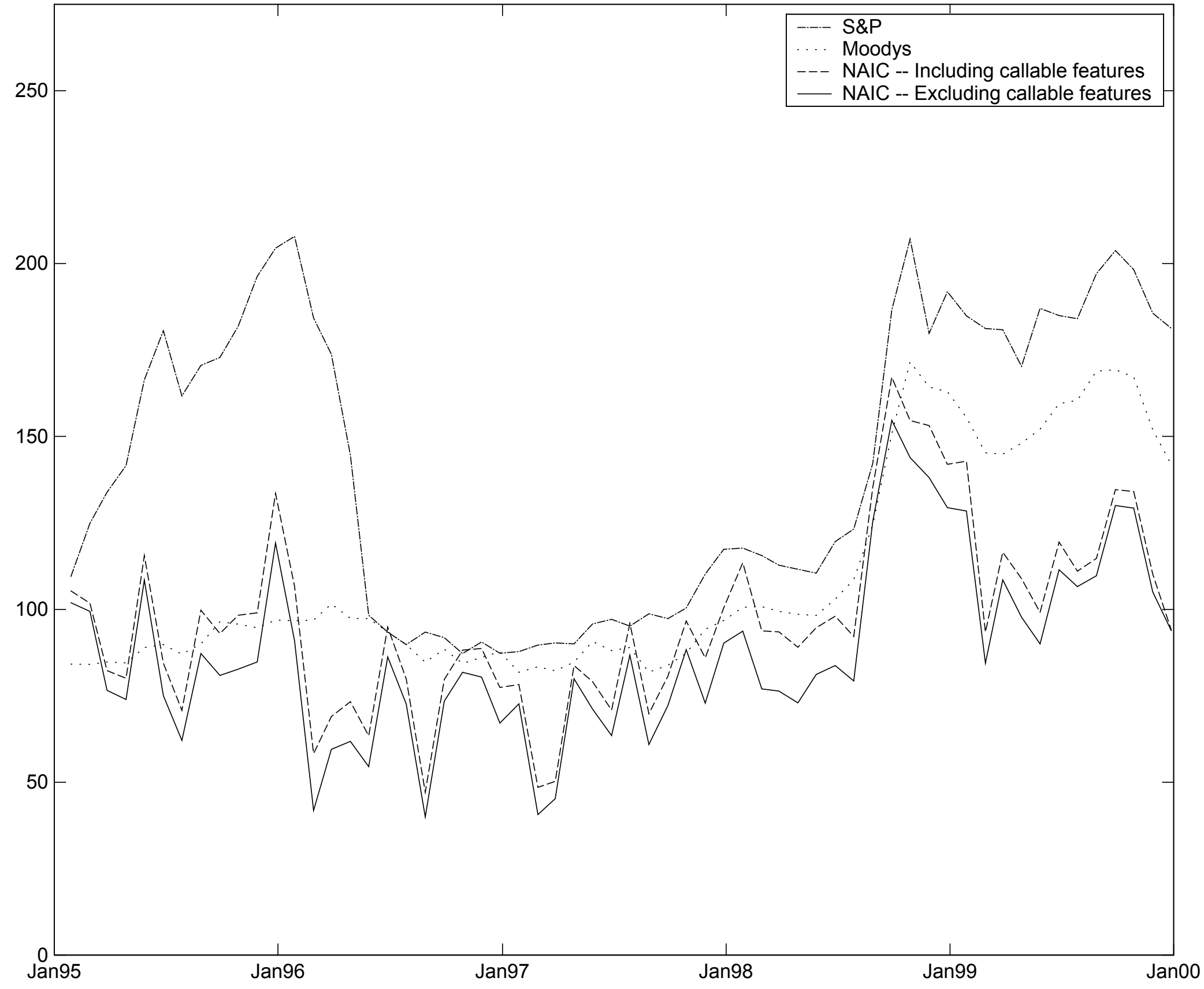


Figure 6. S\&P actual vs. fitted yield spreads for A-rated corporate bonds (bps)

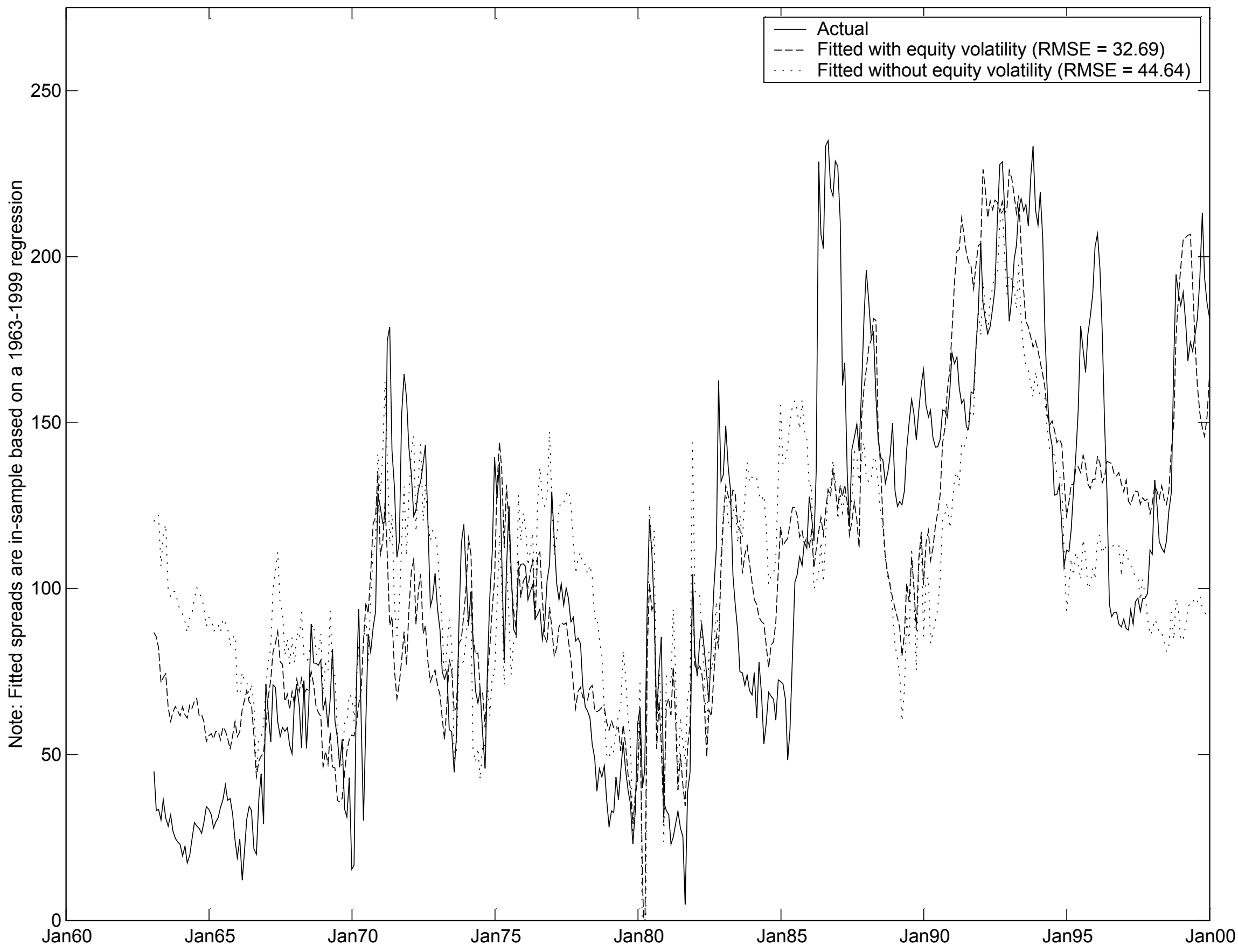


Figure 7. S\&P actual vs. fitted yield spreads for A-rated corporate bonds (bps)

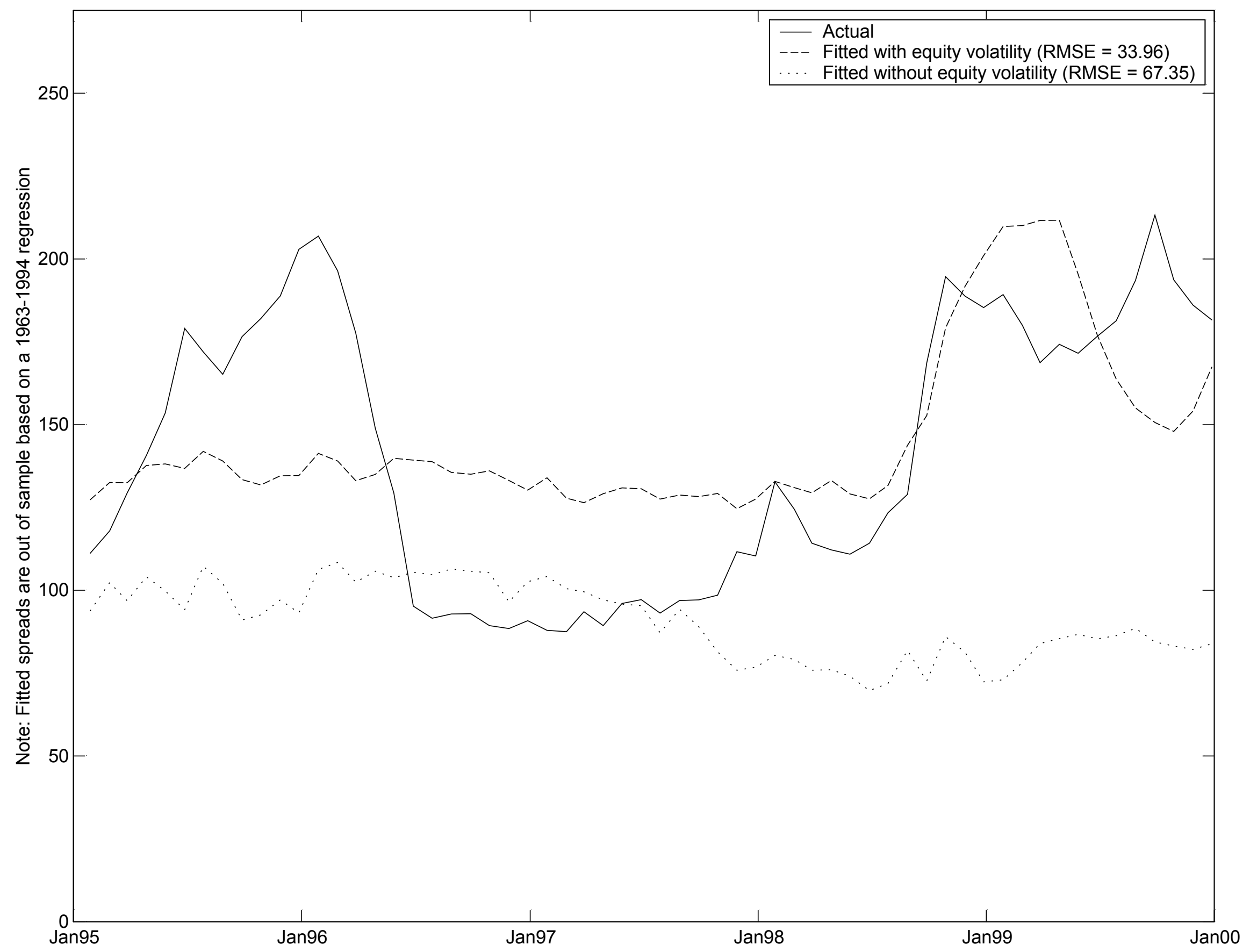

